\title{
Modeling Neurodegenerative Disorders in Drosophila melanogaster
}

\author{
Harris Bolus ${ }^{1}$, Kassi Crocker ${ }^{2,3}$, Grace Boekhoff-Falk ${ }^{3, *}$ and Stanislava Chtarbanova ${ }^{1, *(D)}$ \\ 1 Department of Biological Sciences, University of Alabama, Tuscaloosa, AL 35487, USA; \\ hjbolus@crimson.ua.edu \\ 2 Genetics Graduate Training Program, School of Medicine and Public Health, \\ University of Wisconsin-Madison, Madison, WI 53705, USA; Klcrocker@wisc.edu \\ 3 Department of Cell and Regenerative Biology, School of Medicine and Public Health, \\ University of Wisconsin-Madison, Madison, WI 53705, USA \\ * Correspondence: grace.boekhoff@wisc.edu (G.B.-F.); schtarbanova@ua.edu (S.C.)
}

Received: 18 March 2020; Accepted: 21 April 2020; Published: 26 April 2020

\begin{abstract}
Drosophila melanogaster provides a powerful genetic model system in which to investigate the molecular mechanisms underlying neurodegenerative diseases. In this review, we discuss recent progress in Drosophila modeling Alzheimer's Disease, Parkinson's Disease, Amyotrophic Lateral Sclerosis (ALS), Huntington's Disease, Ataxia Telangiectasia, and neurodegeneration related to mitochondrial dysfunction or traumatic brain injury. We close by discussing recent progress using Drosophila models of neural regeneration and how these are likely to provide critical insights into future treatments for neurodegenerative disorders.
\end{abstract}

Keywords: Drosophila; neurodegeneration; neuroregeneration

\section{Introduction: Drosophila as a Model System for Studies of Human Disease}

The common fruitfly Drosophila melanogaster has been used as a genetic model system for more than 100 years. Because Drosophila are inexpensive to maintain and reproduce rapidly, an enormous repertoire of genetic technologies has been created over the past century [1]. Drosophila possess extensive homology with humans at the genetic level making them a useful model for investigation of the cellular and molecular processes underlying development and disease [2]. Over the past three decades, a variety of human diseases also have been modeled in Drosophila, including many affecting the nervous system [2-4]. Human diseases for which there are Drosophila models are curated by the Bloomington Drosophila Stock Center (https://bdsc.indiana.edu/stocks/hd/index.html). The Drosophila studies are facilitated by the fact that the Drosophila nervous system is complex and possesses many features of our own nervous system including: eyes, olfactory organs, gustatory organs, auditory organs, a ventral nerve cord (spinal cord analog), peripheral sensory neurons for proprioception and pain, and a brain [5] and the generation of huge collections of mutants that impact neural development [6-17]. Moreover, multiple rigorous assays to score neurodegeneration can be used in Drosophila, providing reliable measurements for the effects of the disease process. Such assays include examination of eye morphology and retinal structures by light microscopy, vacuolization of the central brain using histological staining, lifespan analysis, locomotor performance measurements using a climbing assay as well as assessment of neuromuscular junction morphology to determine potential synaptic abnormalities $[18,19]$. Immunohistochemical techniques can be used to label specific subtypes of brain cells such as dopaminergic neurons by using an anti- Tyrosine hydroxylase antibody, or to examine the accumulation of deposits such as amyloid plaques, which are a hallmark of the neuropathology accompanying Alzheimer's Disease using Thioflavin S labeling [18,20]. 
In this review, we focus on several major neurodegenerative diseases being modeled in Drosophila (Figure 1). The diseases discussed here include adult-onset diseases such as Alzheimer's Disease, Parkinson's Disease, Dementia with Lewy Bodies, Amyotrophic Lateral Sclerosis (ALS), Frontotemporal Dementia (FTD) and Huntington's Disease. We also review existing models of Ataxia Telangiectasia, which is a childhood-onset multiorgan disorder, characterized by progressive neurodegeneration as well as emerging models of neurodegenerative diseases with mutations in mitochondrial genes or the Drosophila brain tumor gene. We also discuss Traumatic Brain Injury (TBI) model that is being used to model Chronic Traumatic Encephalopathy (CTE). We conclude with some likely future directions of the Drosophila neurodegeneration field that include use of this powerful model to investigate neural regeneration and how these studies may lead to clinically relevant therapeutics.

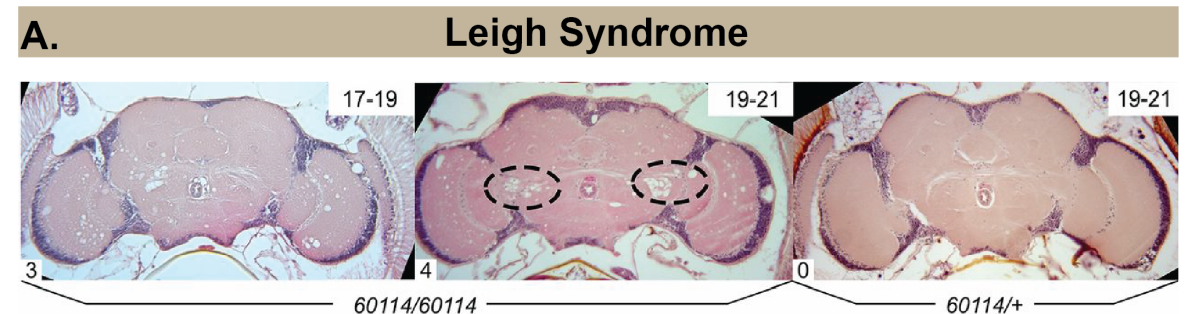

\section{B. Ataxia-telangiectasia}
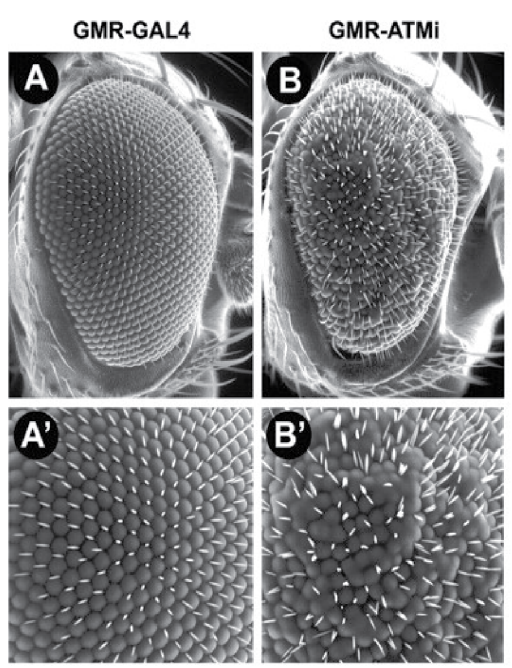

\section{Parkinson's disease}
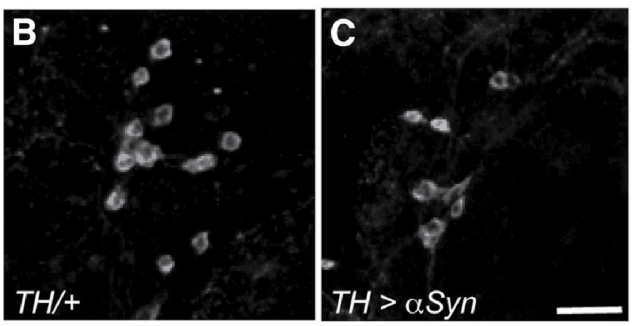

\section{Amyotrophic Lateral Sclerosis}

C.

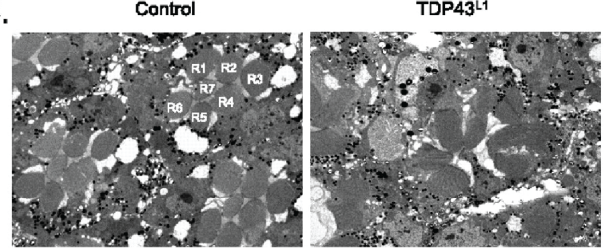

E.

Huntington's disease
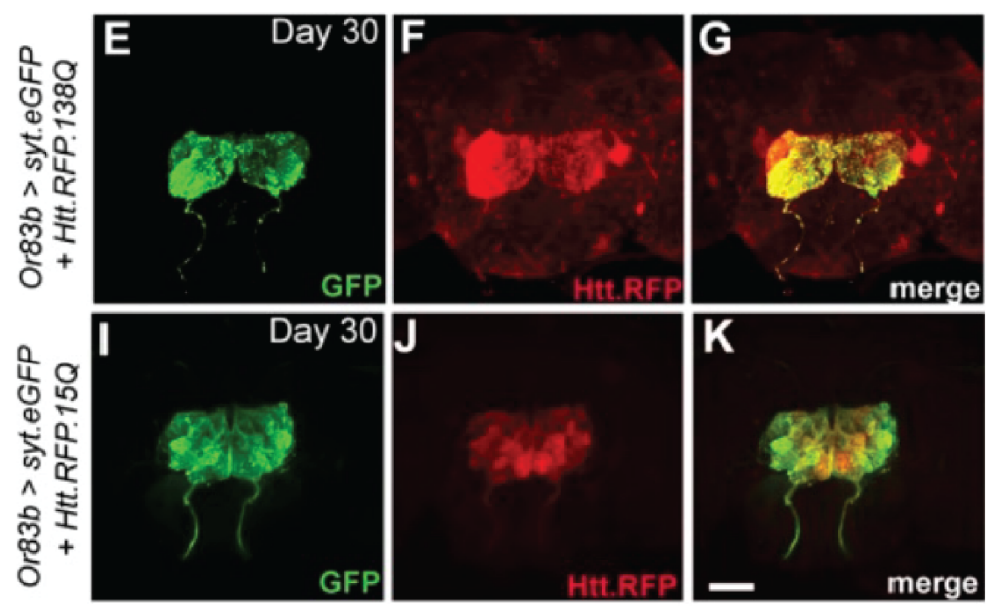

Figure 1. Examples of approaches to examine neuropathology in Drosophila models of different human neurodegenerative diseases. (A) Spongiform pathology in a Drosophila model of Leigh Syndrome, 
revealed by histology and hematoxylin and eosin $(\mathrm{H} \& \mathrm{E})$ staining that shows the appearance of holes in the brain neuropil of 60,114 mutants (ND23 mutants) but not in heterozygous controls (60114/+). Image copyright and permission to use the image were obtained from [21]. (B) Rough eye phenotype (B and B' for magnified image) observed in a Drosophila model of Ataxia Telangiectasia using scanning electron microscopy. Image copyright and permission to use the image were obtained from [22]. (C) Loss of dopaminergic neurons in a Drosophila model of Parkinson's Disease is revealed by immunohistochemistry using an anti-Tyrosine Hydroxylase antibody. Image copyright and permission to use the image were obtained from [23]. (D) Neurodegeneration in photoreceptors (labeled R1-R7) of ommatidia in a Drosophila model of Amyotrophic Lateral Sclerosis (right image) is revealed using Transmission Electron Micrographs. Image copyright and permission to use the image were obtained from [24]. (E). Progressive spreading of Red Fluorescent Protein (RFP)-labeled Huntingtin within the brain is revealed by immunohistochemistry in a Drosophila model of Huntington's Disease. Image copyright and permission to use the image were obtained from [25].

\section{Neurodegenerative Diseases Modeled in Drosophila}

\subsection{Alzheimer's Disease}

Alzheimer's Disease (AD) is a form of dementia that usually manifests after the age of 65 . It is characterized by memory loss, mood and behavior changes, the presence of specific protein aggregates in the brain, and a reduction in brain regions including the hippocampus and temporal lobes [26-28]. AD is one of the leading causes of death in the US; based on data from the 2010 census, 4.7 million individuals over the age of 65 had $\mathrm{AD}$, and an estimated 13.8 million people in the US will have AD by $2050[29,30]$. Although there are no known cures, treatment options include diet and lifestyle interventions, as well as medications that alleviate the symptoms and/or progression of the disease [31,32].

The etiology of $\mathrm{AD}$ is the subject of ongoing research, and different hypotheses have been proposed to account for the variety in associated risk factors and physiological changes. The most prominent of these is the amyloid hypothesis, which holds that the buildup of characteristic extracellular amyloid-beta $(\mathrm{A} \beta)$ aggregates causes pathology, notably neurodegeneration. Pathogenic, extracellular $A \beta 42$ is produced by sequential cleavage of the intramembrane amyloid precursor protein (APP) (in Drosophila, amyloid precursor protein-like (APPL)) by BACE1 ( $\beta$-site APP cleaving enzyme-1), and $\gamma$-secretase. In contrast, non-pathogenic cleavage of APP is carried out by $\alpha$-secretase [33-35]. Another characteristic protein, Tau also is implicated in the amyloid hypothesis. Under normal conditions, Tau binds to microtubules; however, when Tau is hyperphosphorylated, it detaches and forms intracellular aggregates, destabilizing the microtubules and thus decreasing neurotransmission. The cause of Tau hyperphosphorylation is not known, but some data suggest that amyloid pathology contributes, or that they share some mutual causation through a mechanism such as innate immunity. Indeed, activation of the innate immune system and chronic inflammation have been implicated in multiple neurodegenerative disorders [36]. The role of Drosophila brain immunity in the contexts of injury and neurodegeneration is reviewed in [37]. Other hypotheses focus on observations related to Tau tangles, cholinergic dysfunction, mitochondrial dysfunction and oxidative stress, calcium homeostasis, vascular dysfunction, glia-mediated inflammation, metal ion toxicity, and poor lymphatic clearance. These proposed mechanisms are all interrelated, often by the role of $\mathrm{A} \beta$ aggregates, and all may contribute to the development of $\mathrm{AD}$ [35].

Models of AD in Drosophila can be divided into those using mutations in the Drosophila orthologs of human disease genes, transgenic constructs carrying alleles of human disease-causing genes, and models used to study the effects of environmental stressors on $\mathrm{A} \beta$ toxicity (Table 1$)$. Human genes for which Drosophila models have been generated include BACE1, BACE2, PS1, PS2, APP, MEGF10, CD2AP, SNRPN, PTPRD, XYLT1, FERMT2, CELF1, MAST4, ITGAM, and ITGA9 [38-40]. Transgenic constructs have been used to target $A \beta$ production and toxicity; they have also been used to study the 
role of Tau in the pathology of AD [40-48]. Environmental stressors that modulate AD progression and $A \beta$ toxicity include iron, copper, zinc, and light exposure [48-52].

Drosophila homologs of AD-associated genes have provided insights into the human genes implicated in the development of $\mathrm{AD}$ as well as the pathways that contribute to the disease. The gene Draper (in humans, MEGF10), plays a role in the glial engulfment of $A \beta$, reducing neurotoxicity in a Drosophila model of AD [38]. In another study of 87 Drosophila genes, each with a human homolog identified in GWAS as an AD-associated genomic locus, nine were found to strongly affect the toxicity of Tau: CD2AP (cindr), SNRPN (SmB), PTPRD (Lar), XYLT1 (oxt), FERMT2 (Fit 1, Fit 2), CELF1 (aret), MAST4 (CG6498), ITGAM (scb), and ITGA9 (scb) [39]. The proteins encoded by CD2AP and FERMT2 both function with integrins in cell adhesion and signaling; ITGAM and ITGA9 produce $\alpha$-subunits for integrin receptors; and PTPRD and XYLT1 also function in cell adhesion [39,53-56].

The human peptide $A \beta 42$ is well known for forming extracellular plaques in AD. Human A $\beta 42$ has been fused with various signal peptides for secretion in transgenic Drosophila, targeted by an anti-A $\beta 42$ antibody, and expressed with computer-modeled single amino acid substitutions [41-47]. Moreover, in humans, the protein encoded by the gene APP carries the A $\beta$ peptide and is cleaved by BACE1 and $\gamma$-secretase before secretion. Transgenic constructs in Drosophila have investigated APP, BACE1, and pathogenic Psn (the Drosophila ortholog of a $\gamma$-secretase constituent) separately and in combination [20,33,57-61].

Environmental factors, including diet, lifestyle, and chemical exposure, are known to contribute to AD in humans $[62,63]$. The metals iron, copper, and zinc; each found in the human diet; have been studied in Drosophila models of AD, using a variety of methods to increase and decrease exposure. Copper and zinc supplementation exacerbate $A \beta 42$ toxicity, while leveraging chelators, expression of detoxifying proteins, and expression of transport proteins ameliorate toxicity $[50,51]$. Iron chelators, when overexpressed, can also attenuate $A \beta 42$ toxicity and when expression of these chelators is reduced, toxicity increases [49,52]. Reflecting a different aspect of lifestyle and environment, a unique study using a Tau model of AD found that disruption of the circadian rhythm with dim light exposure increased neurodegeneration [48].

Table 1. Drosophila models of Alzheimer's Disease.

\begin{tabular}{|c|c|c|c|}
\hline \multicolumn{4}{|c|}{ Alzheimer's Disease } \\
\hline Drosophila Model & Developmental Stage & Assay Used for Neuropathology & References \\
\hline \multicolumn{4}{|c|}{ Drosophila orthologs of human genes } \\
\hline $\begin{array}{l}\text { Pan-neuronal and } \\
\text { photoreceptor-specific } \\
\text { expression of Drosophila } \\
\text { dBACE and APPL to } \\
\text { produce dA } \beta\end{array}$ & Adult & $\begin{array}{l}\text { Toluidine blue histological staining for retinal } \\
\text { degeneration, Thioflavin } S \text { staining for amyloid } \\
\text { deposits, immunohistochemistry using anti-dA } \beta \text {, } \\
\text { fast phototaxis assay, TEM for fibrillary } \\
\text { aggregates formation and degeneration }\end{array}$ & [40] \\
\hline APPL null mutants & Adult & $\begin{array}{l}\text { Histology for brain morphology, fast phototaxis } \\
\text { assay, olfactory acuity assay, shock reactivity } \\
\text { assay, odor conditioning assay, optomotor assay }\end{array}$ & [64] \\
\hline \multicolumn{4}{|c|}{ Overexpression of human transgenes } \\
\hline $\begin{array}{l}\text { Pan-neuronal and } \\
\text { photoreceptor-specific } \\
\text { expression of } \mathrm{A} \beta 40 \text { and } \mathrm{A} \beta 42 \\
\text { fused to rat pre-proenkephalin } \\
\text { signal peptide (SP) }\end{array}$ & Larva, Adult & $\begin{array}{c}\text { Larvae: immunostaining and confocal } \\
\text { microscopy for } \mathrm{A} \beta 42 \text { accumulation in imaginal } \\
\text { eye discs } \\
\text { Adult: SEM and light stereomicroscopy for eye } \\
\text { morphology, lifespan, immunostaining with } \\
\text { anti-A } \beta \text { (6E10) for A } \beta 42 \text { accumulation, } \\
\text { toluidine blue histological staining for } \\
\text { ommatidial organization }\end{array}$ & [41] \\
\hline $\begin{array}{l}\text { Pan-neuronal expression of } \\
\mathrm{A} \beta 40, \mathrm{~A} \beta 42 \text { and } \mathrm{A} \beta 42^{\mathrm{arc}} \\
\text { fused to Drosophila Necrotic } \\
\text { protein SP }\end{array}$ & Adult & $\begin{array}{c}\text { Lifespan, climbing assay, immunostaining with } \\
\text { anti-A } \beta \text { (4G8) for } A \beta 42 \text { accumulation, SEM for } \\
\text { eye morphology }\end{array}$ & [42] \\
\hline
\end{tabular}


Table 1. Cont.

\begin{tabular}{|c|c|c|c|}
\hline \multicolumn{4}{|c|}{$\begin{array}{l}\text { Alzheimer's Disease } \\
\end{array}$} \\
\hline Drosophila Model & Developmental Stage & Assay Used for Neuropathology & References \\
\hline \multicolumn{4}{|c|}{ Overexpression of human transgenes } \\
\hline $\begin{array}{l}\text { Photoreceptor-specific and } \\
\text { mushroom body-specific } \\
\text { expression of A } \beta 42 \text { fused to } \\
\text { Drosophila Argos SP }\end{array}$ & Adult & $\begin{array}{c}\text { Light microscopy and SEM for retina structure, } \\
\text { light microscopic histology of frontal eye sections } \\
\text { for vacuolar degeneration, immunostaining and } \\
\text { Thioflavin S staining for A } \beta 42 \text { accumulation } \\
\text { in eyes }\end{array}$ & [43] \\
\hline $\begin{array}{l}\text { Photoreceptor-specific } \\
\text { expression of A } \beta 42 \\
\text { and blocking }\end{array}$ & Larva, Pupa, Adult & $\begin{array}{c}3^{\text {rd }} \text { Instar Larvae: immunostaining for eye } \\
\text { imaginal disc development and A } \beta 42 \\
\text { accumulation, TUNEL staining for eye imaginal } \\
\text { disc cell death, } \\
\text { Pupae: immunostaining for eye development } \\
\text { and A } \beta 42 \text { accumulation } \\
\text { Adult: immunostaining for eye development and } \\
\text { A } \beta 42 \text { accumulation, histology for photoreceptor } \\
\text { morphology, SEM for eye morphology, }\end{array}$ & [44] \\
\hline $\begin{array}{l}\text { Expression of various mutated } \\
\text { A } \beta 42 \text { peptides for the effect of } \\
\text { specific amino acid } \\
\text { substitutions on toxicity }\end{array}$ & Adult & $\begin{array}{c}\text { Lifespan, locomotor assay, } \\
\text { immunohistochemistry using anti- } \mathrm{A} \beta 42, \\
\text { Thioflavin T staining for rates of } \mathrm{A} \beta 42 \\
\text { aggregation, TEM for } \mathrm{A} \beta 42 \\
\text { aggregate morphology }\end{array}$ & [45] \\
\hline $\begin{array}{l}\text { Expression of various mutated } \\
\text { A } \beta 42 \text { peptides for the effect of } \\
\text { specific amino acid } \\
\text { substitutions on toxicity }\end{array}$ & Adult & Lifespan & [46] \\
\hline $\begin{array}{c}\text { Pan-neuronal and } \\
\text { muscle-specific expression of } \\
\text { A } \beta 42 \text {, exposure to exogenous } \\
\text { A } \beta 42 \text {, and treatment with } \\
\text { anti-A } \beta 42 \text { antibody }(6 E 10)\end{array}$ & Larva & $\begin{array}{c}\text { 3rd Instar Larvae: Electrophysiology for synaptic } \\
\text { transmission, FM1-43 dye imaging for } \\
\text { neurotransmitter release, Thioflavin S staining } \\
\text { for amyloid deposits }\end{array}$ & [47] \\
\hline $\begin{array}{l}\text { Pan-neuronal and } \\
\text { photoreceptor-specific } \\
\text { expression of two human Tau } \\
\text { variants, manipulation of } \\
\text { light exposure }\end{array}$ & Adult & $\begin{array}{l}\text { Lifespan, histology, and light microscopy to } \\
\text { quantify neurodegeneration, climbing assay, } \\
\text { immunohistochemistry for pTau accumulation, } \\
\text { light microscopy for eye morphology }\end{array}$ & [48] \\
\hline $\begin{array}{l}\text { Pan-neuronal expression of } \\
\text { human APP and BACE1 } \\
\text { separately and in combination, } \\
\text { treatment with a } \\
\gamma \text {-secretase inhibitor }\end{array}$ & Adult & $\begin{array}{l}\text { Lifespan, fluorescence microscopy for defects in } \\
\text { the whole-brain and mushroom body structure, } \\
\text { immunostaining with anti- } A \beta(6 E 10) \text {, Thioflavin } \\
S \text {, and } X-34 \text { for amyloid deposition, climbing } \\
\text { assay, conditioned courtship suppression assay }\end{array}$ & [57] \\
\hline $\begin{array}{l}\text { Expression of human BACE1 } \\
\text { and late-onset induction of } \\
\text { human APP }\end{array}$ & Adult & $\begin{array}{l}\text { Lifespan, climbing assay, immunostaining with } \\
\text { anti-A } \beta \text { (6E10) for amyloid deposition, } \\
\text { fluorescence microscopy for defects in the } \\
\text { whole-brain and mushroom body structure, } \\
\text { conditioned courtship suppression assay }\end{array}$ & [58] \\
\hline \multicolumn{4}{|c|}{ Combined models of Drosophila orthologs and overexpression of human transgenes } \\
\hline $\begin{array}{l}\text { Knockdown of orthologs of } \\
\text { human CD2AP, SNRPN, } \\
\text { PTPRD, XYLT1, FERMT2, } \\
\text { CELF1, ITGAM, ITGA9, } \\
\text { MAST4 in Drosophila } \\
\text { overexpressing } \\
\text { human Tau }{ }^{\text {V337M }}\end{array}$ & Adult & Light microscopy for eye morphology & [39] \\
\hline $\begin{array}{l}\text { Expression of Drosophila Psn, } \\
\text { Drosophila APPL, human APP, } \\
\text { and human BACE, separately } \\
\text { and in combination }\end{array}$ & Adult & $\begin{array}{c}\text { Histological staining for retinal degeneration, } \\
\text { Thioflavin } S \text { and immunostaining with anti- } A \beta \\
\text { (4G8) for } A \beta \text { accumulation in retinas, survival } \\
\text { assay, lifespan }\end{array}$ & [20] \\
\hline $\begin{array}{l}\text { A } \beta 42^{\text {arc }} \text { overexpression, } \\
\text { Draper inhibition, } \\
\text { overexpression of } \\
\text { Draper/MEGF10 }\end{array}$ & Adult & $\begin{array}{l}\text { Lifespan, Thioflavin } \mathrm{S} \text { and anti-A } \beta \text { (6E10) } \\
\text { immunostaining for } \mathrm{A} \beta \text {, climbing assay, } \\
\text { histological sectioning for vacuole quantification }\end{array}$ & [38] \\
\hline
\end{tabular}


Table 1. Cont.

\begin{tabular}{|c|c|c|c|}
\hline \multicolumn{4}{|c|}{ Alzheimer's Disease } \\
\hline Drosophila Model & Developmental Stage & Assay Used for Neuropathology & References \\
\hline \multicolumn{4}{|c|}{ Combined models of Drosophila orthologs and overexpression of human transgenes } \\
\hline $\begin{array}{c}\text { Photoreceptor-specific } \\
\text { expression of human A } \beta 42 \text { in } \\
\text { eyes, supplementation with } \\
\text { zinc or copper, treatment with } \\
\text { chelators, and overexpression } \\
\text { of MTF-1 }\end{array}$ & Larva, Adult & $\begin{array}{l}\text { Larva: relative eclosion rate } \\
\text { Adults: Stereomicroscopy for ommatidia } \\
\text { structure, climbing assay }\end{array}$ & [50] \\
\hline $\begin{array}{c}\text { Pan-neuronal expression of } \\
\text { A } \beta 42, \text { treatment with an iron } \\
\text { chelator, and RNAi } \\
\text { knockdown of ferritin }\end{array}$ & Embryo, Adult & $\begin{array}{c}\text { Embryos: Hatching efficiency assay } \\
\text { Adults: Survival assay, Thioflavin T staining for } \\
\text { amyloid aggregation }\end{array}$ & [49] \\
\hline $\begin{array}{l}\text { Photoreceptor-specific } \mathrm{A} \beta 42 \\
\text { expression, over- and } \\
\text { under-expression of an } \\
\text { immunophilin, mutation in a } \\
\text { copper transporter, } \\
\text { and treatment with an } \\
\text { exogenous copper chelator }\end{array}$ & Adult & Lifespan, light microscopy for eye morphology & [51] \\
\hline
\end{tabular}

\subsection{Lewy Body Dementias: Parkinson's Disease and Dementia with Lewy Bodies}

Lewy Body Dementias (LBDs) are characterized by aggregates of $\alpha$-synuclein ( $\alpha$-syn) within cells of the brain. These aggregates are called Lewy bodies. There are two types of LBD: Parkinson's disease (PD) and Dementia with Lewy Bodies (DLB). Overexpression of $\alpha$-syn in Drosophila could be considered to model PD, DLB, or both. However, publications to date refer to $\alpha$-syn overexpression in Drosophila as PD models. We maintain that convention here and therefore do not discuss DLB further. PD is a neurodegenerative disease that affects individuals over the age of 45 at a rate of $572 / 100,000$ in North America. The number of people with PD in the United States is expected to reach 930,000 in 2020 [65]. The characteristic symptoms of PD include tremor and posture instability, which are caused by a loss of midbrain dopaminergic (DA) neurons that deliver dopamine to the basal ganglia [66]. Other brain structures also are affected, such as the cerebral cortex, post-commissural putamen, and olfactory tubercle, leading to diverse symptoms [66]. There are no known cures for the condition, but medications that target dopamine receptors, such as levodopa and dopamine agonists, are effective at treating the symptoms [67]. Other non-pharmacological treatments, such as deep brain stimulation and exercise therapy, may also be effective [68].

Among the molecular mechanisms contributing to PD pathology are neuroinflammation, defects in $\alpha$-syn proteostasis, mitochondrial dysfunction, oxidative stress, perturbation of calcium homeostasis and defects in axonal transport [67]. Because the etiology of PD is multifactorial, a variety of models have been generated in Drosophila to reflect known contributing factors (Table 2). Orthologous genes, transgenic constructs carrying human genes, and environmental factors all have been investigated. The Parkinson's disease-related genes that have exploitable homologs in Drosophila include PARK2, PINK1, LRRK2, DJ-1, UCH-L1, HtrA2, GBA, and Tau [69-80]. $\alpha$-Syn and Pael-R do not have Drosophila homologs, and are studied using transgenic models [79,81]; human transgenes also have been introduced for other genes including LRRK2 and Tau $[79,82,83]$. Moreover, environmental stressors, such as the widely used pesticides rotenone and paraquat, have been tested on Drosophila [84-86]. 
Table 2. Drosophila models of Parkinson's disease.

\begin{tabular}{|c|c|c|c|}
\hline \multicolumn{4}{|c|}{ Parkinson's Disease } \\
\hline Drosophila Model & Developmental Stage & Assay Used for Neuropathology & References \\
\hline \multicolumn{4}{|c|}{ Drosophila orthologs of human genes } \\
\hline Parkin mutants & Adult & TH immunostaining, climbing assay & [78] \\
\hline $\begin{array}{l}\text { PINK1 mutants } \\
\text { PINK1 knock down in } \\
\text { DA neurons }\end{array}$ & Adult & $\begin{array}{l}\text { Lifespan, TH immunostaining, chemotaxis } \\
\text { assay, dopamine enzyme immunoassay, HPLC } \\
\text { for DA tissue and dopamine levels, fast-scan } \\
\text { cyclic voltammetry, RT-PCR for DAT and } \\
\text { GAPDH2, Western blot for TH, mobility assay }\end{array}$ & {$[69,75,76,80]$} \\
\hline LRRK2 mutants & Adult & Climbing assay, TH immunostaining & [71] \\
\hline $\begin{array}{l}\text { DJ-1 mutants exposed to } \\
\text { hydrogen peroxide, } \\
\text { paraquat and rotenone }\end{array}$ & Adult & Lifespan, TH immunostaining & [74] \\
\hline $\begin{array}{l}\text { Photoreceptor cell-specific } \\
\text { overexpression of dUCH and } \\
\text { DA neurons-specific } \\
\text { knockdown of dUCH }\end{array}$ & Larva, Pupa, Adult & $\begin{array}{l}\text { SEM for eye morphology, activated-Caspase } 3 \\
\text { immunostaining, TH immunostaining, } \\
\text { larval crawling assay, adult climbing assay, } \\
\text { pupal retinal mispatterning determination }\end{array}$ & [77] \\
\hline $\begin{array}{l}\text { HtrA2 knockdown in DA } \\
\text { neurons and } \\
\text { photoreceptor cells }\end{array}$ & Adult & $\begin{array}{l}\text { Lifespan, climbing assay, SEM for } \\
\text { eye morphology }\end{array}$ & [72] \\
\hline $\begin{array}{l}\text { Double heterozygous GBA } \\
\text { mutants (CG31414 and } \\
\text { CG31148) }\end{array}$ & Adult & Lifespan, TH immunostaining, climbing assay & [73] \\
\hline $\begin{array}{l}\text { Overexpression of dTau in } \\
\text { mushroom body neurons }\end{array}$ & Adult & $\begin{array}{c}\text { Survival up to } 30 \text { days of age, learning and } \\
\text { memory assays }\end{array}$ & [87] \\
\hline \multicolumn{4}{|c|}{ Overexpression of human transgenes } \\
\hline $\begin{array}{l}\text { Co-expression of Tau and } \\
\text { Alpha-Synuclein ( } \alpha \text {-syn) }\end{array}$ & Larva, Adult & $\begin{array}{l}\text { Activated-caspase } 3 \text { immunostaining, larval } \\
\text { NMJ morphology, TH immunostaining, SEM } \\
\text { for adult eye morphology }\end{array}$ & [83] \\
\hline $\begin{array}{l}\text { Pan-neuronal, photoreceptor } \\
\text { cell- and DA neurons-specific } \\
\text { overexpression of wild type, } \\
\text { A30P and A53T } \alpha \text {-syn }\end{array}$ & Adult & $\begin{array}{l}\text { H\&E staining, TH immunostaining, Lewy body } \\
\text { detection using Ubiquitin immunostaining, } \\
\text { TEM for neuronal } \alpha \text {-syn inclusions, } \\
\text { climbing assay, Toluidine blue staining of } \\
\text { tangential retinal sections }\end{array}$ & [81] \\
\hline $\begin{array}{l}\text { Pan-neuronal, photoreceptor } \\
\text { cell- and DA neurons-specific } \\
\text { overexpression of LRRK2 and } \\
\text { LRRK2-G2019S-2 }\end{array}$ & Adult & $\begin{array}{l}\text { Lifespan, climbing assay, TEM for } \\
\text { photoreceptor morphology in ommatidia, } \\
\text { TH immunostaining, actometer test }\end{array}$ & [82] \\
\hline $\begin{array}{l}\text { Overexpression of Pael-R in } \\
\text { DA neurons }\end{array}$ & Adult & TH immunostaining & [79] \\
\hline \multicolumn{4}{|c|}{ Toxin exposure } \\
\hline Rotenone & Adult & TH immunostaining, climbing assay & [84] \\
\hline Paraquat & Adult & $\begin{array}{l}\text { TH immunostaining, lifespan, climbing assay, } \\
\text { jumping assay, Dopamine levels }\end{array}$ & {$[85,86]$} \\
\hline
\end{tabular}

Functions of the Drosophila orthologs of genes associated with PD can be investigated using mutant flies or by tissue and/or cell-specific overexpression or knock down using binary expression systems [88]. The PARK2 gene codes for the protein Parkin, which targets abnormal proteins for degradation. The PD-related proteins Pael-R and $\alpha-$ Syn are among those surveilled by PARK2 [79]. Importantly, Drosophila brains, as with human brains, have dopaminergic (DA) neurons. Thus, the consequences of particular mutations and gene overexpression can be examined in DA neurons. In Drosophila, PINK1 protein is important for mitochondrial function, and PINK1 mutants have fewer DA neurons and exhibit both olfactory dysfunction and motor deficits $[69,75,76,80]$. Drosophila $L R R K 2$ loss-of-function mutations also reduce DA neuron numbers and cause impaired locomotor activity [71]. DA neuron-specific knockdown of the Drosophila ortholog of $U C H-L 1, d U C H$, leads to Parkinson's disease-like phenotype illustrated by the loss of DA neurons, while its overexpression leads to caspase-dependent cell death in eye imaginal discs, aberrant patterning of the pupal retina 
and a rough eye phenotype in the adult [77]. The HtrA2 protein has protease activity and is involved in apoptosis. Knockdown of HtrA2 function in Drosophila DA neurons and photoreceptor cells decreases lifespan, motor ability, and ommatidia number [72]. The gene GBA encodes $\beta$-glucocerebrosidase, which is necessary for preventing accumulation of glucosylceramides. GBA mutations in Drosophila result in DA cell death, motor deficits, and decreased lifespan [73]. The protein Tau can form neurotoxic inclusions that are implicated in both human PD and AD [70]. Overexpression of Drosophila Tau in mushroom body neurons results in learning and memory defects [87]. Tau toxicity in Drosophila is increased by both over- and under-expression of LRRK2, and is characterized by loss of tyrosine hydroxylase (TH)-immunoreactive neurons [89].

Because flies lack orthologs of human $\alpha-S y n$ or Pael-R, overexpression of human cDNAs has been used to investigate their functions in Drosophila. Overexpression of variants of human $\alpha$-Syn in Drosophila, leads to locomotor defects, Lewy body formation in the brain and retinal degeneration [81]. Co-expression of the human proteins $\alpha$-Syn and Tau, in a Drosophila model, leads to the formation of inclusions of ubiquitinylated proteins that disrupt functions of the cytoskeleton, causing neurodegeneration [83]. Overexpression of wild type and mutant human LRRK2 in Drosophila leads to degeneration in photoreceptor cells and neurons along with symptoms including motor deficit and decreased lifespan [82].

The pesticides rotenone and paraquat have been linked to the development of PD in humans, and Drosophila models of PD have been used to investigate the mechanisms by which this occurs [84-86,90]. Rotenone inhibits mitochondrial Complex I, causing oxidative stress. In flies, rotenone causes dose-dependent symptoms including motor deficits and selective DA neuron loss. Moreover, the PD medication L-dopa can be used to treat the motor deficits but not DA neuron loss [84]. Paraquat exposure in Drosophila also induces oxidative stress and DA neuron loss [85]. These changes are similar to those observed in post-mortem samples of paraquat-exposed PD patients [91,92]. Recent studies in Drosophila have demonstrated that paraquat exposure also leads to deregulated innate immune responses [90]. It remains unclear whether deregulation of the innate immune response is a primary contributor to neurodegeneration following paraquat exposure; however, activation of the innate response has been linked to neurodegeneration in other contexts (e.g., [93]).

\subsection{Amyotrophic Lateral Sclerosis and Frontotemporal Dementia}

ALS is characterized by the progressive degeneration of motor neurons. ALS is a relatively rare, but rapidly progressing, neurodegenerative disease that usually leads to death within 5 years of diagnosis. Familial ALS (FALS) accounts for $\sim 10 \%$ of ALS cases, while sporadic ALS (SALS) accounts for the remaining $~ 90 \%$ [94]. A variety of genes have been implicated in ALS. Seven of these genes have been used to generate Drosophila ALS models (Table 3). These are: C9ORF72, TDP-43, FUS, VAPB, $U B Q L N 2, V C P$, and $S O D-1$. Overexpression, reduced expression, and expression of mutant versions of these genes have been used productively in Drosophila. A variety of assays also have been employed including measurement of lifespan, assessment of locomotion; examination of neuromuscular junction (NMJ) phenotypes; quantification of retinal degeneration and sensory neuron dendritic branching.

Frontotemporal dementia (FTD) is a group of disorders characterized by degeneration of the frontal and temporal lobes of the brain. It often has an early onset. Genes that contribute to FTD include: C9ORF72, FUS, VCP, TDP-43, MAPT/tau, CHMP2B, PGRN, TBK1, and TMEM106B (reviewed in [95]), thus there is overlap with other neurodegenerative diseases including: ALS (C9ORF72, FUS, VCP and TDP-43), AD (tau) and PD (tau). C9ORF72, FUS, VCP, and TDP-43 studies in Drosophila are included in Table 3, while tau studies are listed in Tables 1 and 2. 
Table 3. Drosophila models of Amyotrophic Lateral Sclerosis.

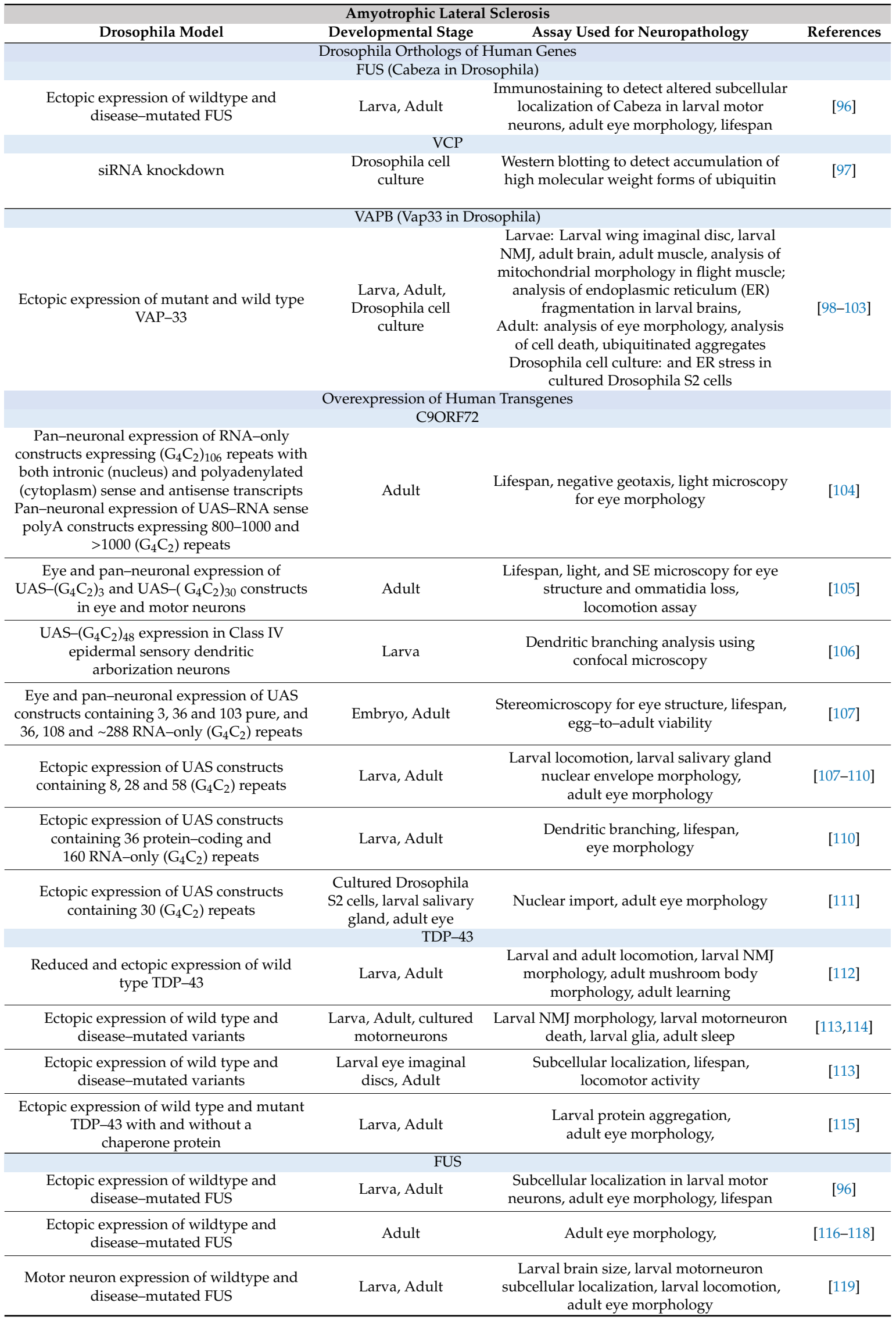


Table 3. Cont.

\begin{tabular}{|c|c|c|c|}
\hline \multicolumn{4}{|c|}{ Amyotrophic Lateral Sclerosis } \\
\hline Drosophila Model & Developmental Stage & Assay Used for Neuropathology & References \\
\hline \multicolumn{4}{|c|}{ Overexpression of Human Transgenes } \\
\hline \multicolumn{4}{|c|}{ UBQLN1/2 } \\
\hline $\begin{array}{l}\text { Ectopic expression of wild type and } \\
\text { disease variants }\end{array}$ & Adult & $\begin{array}{l}\text { Measurement of TDP-43 levels in adult } \\
\text { eye lysates }\end{array}$ & [120] \\
\hline $\begin{array}{l}\text { Co-expression of human UBQLN } \\
\text { and TDP-43 }\end{array}$ & Larva, Adult & $\begin{array}{c}\text { Larval NMJ morphology, lifespan, } \\
\text { measurement of TDP-43 levels in adult head } \\
\text { lysates, adult eye morphology, } \\
\text { adult locomotion assays }\end{array}$ & {$[24,121]$} \\
\hline \multicolumn{4}{|c|}{ ( } \\
\hline $\begin{array}{l}\text { Expression of wild type human VAPB in } \\
\text { Drosophila neurons }\end{array}$ & Larva & $\begin{array}{c}\text { Larvae: Rescues lethality, NMJ morphology, } \\
\text { and NMJ electrophysiology of } \\
\text { loss-of-function mutations in } \\
\text { Drosophila VAP-33 }\end{array}$ & [122] \\
\hline \multicolumn{4}{|c|}{ 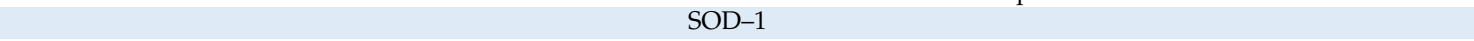 } \\
\hline $\begin{array}{l}\text { Ectopic expression of wild type and } \\
\text { disease variants }\end{array}$ & Adult & $\begin{array}{l}\text { Lifespan, locomotion, number of } \\
\text { motorneurons, neuronal SOD-1 } \\
\text { accumulation, glial stress response }\end{array}$ & [123] \\
\hline
\end{tabular}

The most common contributing factor to ALS is a particular repeat expansion in the gene C9ORF72 that contains hundreds or thousands of the intronic hexanucleotide repeat $\left(\mathrm{G}_{4} \mathrm{C}_{2}\right)_{n}[124,125]$. Hexanucleotide repeat expansion (HRE) has been found in more than $5 \%$ of SALS patients and $39 \%$ of white American and European FALS patients, although it may be less common in other ethnic groups [126]. Repeat RNA can be neurotoxic. However, repeat-associated non-AUG (RAN) translation from these RNAs also can give rise to dipeptide repeat (DPR) proteins, which can be neurotoxic $[127,128]$.

Several strategies have been used in Drosophila to introduce precise $\mathrm{G}_{4} \mathrm{C}_{2}$ repeats and to investigate the potential neurotoxicity mechanisms (Table 3). In one study, as few as 30 repeats were found to be sufficient to cause neurodegeneration [105]. A subsequent study compared a variety of RNA-only expression methods, which was accomplished by interspersing stop codons that prevented dipeptide repeat (DPR) protein production. In this study, the RNA carrying the HRE did not result in toxicity, and the DPR proteins encoded by the hexanucleotide repeats were thought to mediate neurotoxicity [104]. Consistent with this, when the effects have been compared of expressing RNA that would code for different dipeptide combinations without using the $\mathrm{G}_{4} \mathrm{C}_{2}$ motif, only arginine-containing DPR proteins were neurotoxic [107]. The Drosophila studies contrast with results in zebrafish where both DPR proteins and clusters of the mutant RNA are neurotoxic $[129,130]$.

Both protein and RNA aggregates typically are observed in motor neurons of ALS patients post-mortem. Furthermore, these aggregates commonly contain both ubiquitin and TDP-43, thereby uniting multiple ALS genes in a common, proteostasis-defective, program. TDP-43 encodes the transactive response (TAR) DNA-binding protein, which can bind to both DNA and RNA. Mutations in TDP-43 account for $\sim 4 \%$ of FALS cases. TDP-43 protein is normally found in the nucleus, but localizes the cytoplasm in $90 \%$ of ALS patient samples. Indeed, cytoplasmic aggregates of TDP-43 are found in $\sim 90 \%$ of SALS brain and spinal cord specimens, making these aggregates one of the most reliable ALS diagnostics [94]. TDP-43 is a heterogeneous nuclear ribonucleoprotein (hnRNP) with demonstrated roles in transcription, mRNA splicing, and mRNA transport. It recognizes a UG-repeat sequence in target RNAs. Multiple mechanisms for TDP-43 toxicity have been proposed. One possibility is that TDP-43 functions in part by suppressing the incorporation of cryptic exons into mRNAs; without normal TDP-43 activity, aberrant transcripts are made that encode aberrant proteins. These RNAs and proteins overwhelm the degradation machinery, forming neurotoxic aggregates.

The Drosophila ALS models provide unique and powerful tools for understanding the etiology of ALS. Sophisticated genetic analyses that are not feasible in other systems have permitted the identification of both cell-autonomous and non-autonomous mechanisms of neurotoxicity [99] and facilitated analysis of protein vs. RNA contributions to neurotoxicity [104,107]. In addition, application of advanced genetic techniques has permitted the identification of interacting loci for known ALS 
genes [131-135]. These genetic interactions, in turn, have provided insights into the molecular mechanisms underlying neurodegeneration in ALS patients and provide a platform for the assaying of potential ALS therapeutics [136].

\subsection{Huntington's Disease}

Huntington's disease (HD), as with ALS, is caused by repeat expansion mutations. It involves a trinucleotide repeat that results in a polyglutamine (polyQ) segment of 36 or more units in the Huntingtin (Htt) protein [137,138]. It is usually diagnosed between the ages of 30 and 50, and symptoms include progressive problems of coordination, learning ability, decision making, and mood, although it can begin earlier in life with different signs and symptoms [139]. It is most common in European, North American, and Australian populations at 5.7 cases per 100,000 people, as compared to 0.4 cases per 100,000 people in Asian populations [140]. Life expectancy after diagnosis is only 17-20 years and no known treatments can slow the disease's progression, although some can address symptoms such as chorea $[139,140]$.

Because the Drosophila Huntingtin (dHtt) does not have expanded polyQ in its amino terminus [141], most models of HD in Drosophila introduce the mutant human gene transgenically, and focus on large polyQ domains as versus studying the entire protein (Table 4). Much of the variation in Drosophila models of HD is based on which segments of the Htt protein are expressed. In some studies, expression of fragments of the gene such as exon one only or the first three exons was used, while in others, large segments such as a 12-exon fragment or the sequence encoding the entire protein were used [142-145]. To introduce compounds of interest, inhibitors of polyQ aggregation such as QBP1 (polyglutamine binding peptide) and bivalent polyQ peptides have been transgenically expressed, genes such NMNAT (nicotinamide mononucleotide adenylyltransferase) have been overexpressed, HDAC (histone deacetylase) inhibitors have been administered through food, and polyQ aggregation inhibitors have been delivered using nanoparticles [144,146-148]. Of course, alongside overexpression of genes such as NMNAT, which leads to reduction in mutant Htt aggregation by promoting autophagic clearance, loss-of-function mutations and conditional expression (after symptoms appear) have also proven useful for investigating pathology and treatment [148]. Treatment with HDAC inhibitors was shown to halt polyglutamine-induced toxicity and improve lethality. Moreover, assays including survival, photoreceptor quantification, circadian rhythmicity, and motor performance are conducive to screening for treatments or deficiency mutations [142,145]. While not a direct assay for neuropathology, circadian rhythm changes are strongly correlated with neurodegeneration in humans as well as animal models [149,150].

Table 4. Drosophila models of Huntington's disease.

\begin{tabular}{|c|c|c|c|}
\hline Drosophila Model & Developmental Stage & Assay Used for Neuropathology & References \\
\hline \multicolumn{4}{|c|}{ Huntington's Disease } \\
\hline \multicolumn{4}{|c|}{ Drosophila orthologs of human genes } \\
\hline $\begin{array}{l}\text { Fly } \mathrm{dHtt} \text { does not express polyQ in } \\
\text { its N-terminus }\end{array}$ & N/A & N/A & [141] \\
\hline \multicolumn{4}{|c|}{ Overexpression of human transgenes } \\
\hline $\begin{array}{l}\text { Transgenic expression of a Q48 peptide } \\
\text { or Htt Exon1p in neurons }\end{array}$ & Adult & $\begin{array}{l}\text { Lifespan, photoreceptor } \\
\text { morphology count }\end{array}$ & [144] \\
\hline $\begin{array}{l}\text { Transgenic expression of various } \\
\text { Q48 constructs }\end{array}$ & Adult & $\begin{array}{l}\text { Locomotor, photoreceptor } \\
\text { morphology count }\end{array}$ & [151] \\
\hline $\begin{array}{l}\text { Transgenic expression of Q108 and Q48 } \\
\text { peptides, transgenic expression of } \\
\text { bivalent polyQ peptides }\end{array}$ & Adult & $\begin{array}{l}\text { Lifespan, photoreceptor } \\
\text { morphology count }\end{array}$ & [152] \\
\hline Expression of Q127 and Q20 peptides & Adult & $\begin{array}{l}\text { SEM and light microscopy for retina } \\
\text { morphology, light microscopy for } \\
\text { pigmentation defects, staining with } \\
\text { FITC for presence of polyQ aggregates }\end{array}$ & [153] \\
\hline
\end{tabular}


Table 4. Cont.

\begin{tabular}{|c|c|c|c|}
\hline Drosophila Model & Developmental Stage & Assay Used for Neuropathology & References \\
\hline \multicolumn{4}{|c|}{ Huntington's Disease } \\
\hline \multicolumn{4}{|c|}{ Overexpression of human transgenes } \\
\hline $\begin{array}{c}\text { Expression of mRFP-tagged N-terminal } \\
\text { fragments of human Q15 or } \\
\text { Q138 peptides }\end{array}$ & Adult & $\begin{array}{l}\text { Lifespan, locomotion, } \\
\text { activated-Caspase } 3 \text { immunostaining, } \\
\text { immunostaining for brain size }\end{array}$ & [148] \\
\hline $\begin{array}{c}\text { Expression of an mRFP-tagged } \\
\text { N-terminal fragment of human Q15 or } \\
\text { Q138 peptides containing exons 1-12 }\end{array}$ & Adult & $\begin{array}{l}\text { Immunofluorescence for spreading of } \\
\text { Huntingtin aggregates in the brain }\end{array}$ & [25] \\
\hline $\begin{array}{l}\text { Expression of several 3- or 1-exon } \\
\text { sections of mutant Htt with various } \\
\text { polyQ lengths in clock neurons and } \\
\text { ventral lateral neurons (sLNvs), RNAi } \\
\text { knockdown of heat shock protein (Hsp) }\end{array}$ & Adult & $\begin{array}{l}\text { Htt-eGFP fusions to track and quantify } \\
\text { aggregation, sLNv count, rhythmicity, } \\
\text { confocal imaging for PER protein } \\
\text { intensity, transcript levels of } \\
\text { Hop-associated proteins }\end{array}$ & [145] \\
\hline Expression of Q93 and Q20 peptides & Adult, Larva & $\begin{array}{l}\text { Adult: locomotion } \\
\text { Larva: crawling assay }\end{array}$ & [146] \\
\hline $\begin{array}{l}\text { Temperature-inducible expression of a } \\
\text { Q15 or Q138 12-exon fragment of the } \\
\text { human Htt gene, or expression of a } \\
548 \text { amino acid Q0 or Q128 segment of } \\
\text { human Htt }\end{array}$ & $\begin{array}{l}\text { Adult, pharate adult, } \\
\text { larva }\end{array}$ & $\begin{array}{l}\text { Adult: RFP tag for imaging of Htt } \\
\text { aggregation and localization } \\
\text { Pharate adult: lethality } \\
\text { Larvae: viability past 2nd instar for } \\
\text { small molecule screen, Fluorescence } \\
\text { recovery after photobleaching for } \\
\text { aggregate growth }\end{array}$ & [142] \\
\hline $\begin{array}{l}\text { Expression of full-length Q128 or Q16 } \\
\text { human Htt }\end{array}$ & Adult, larva & $\begin{array}{l}\text { Adults: Western blot for Huntingtin } \\
\text { levels, photoreceptor morphology } \\
\text { count, locomotion, flying assay, } \\
\text { confocal microscopy to count neuronal } \\
\text { projections into IFMs } \\
\text { Larvae: immunohistochemistry for } \\
\text { third-instar larval NMJ count, } \\
\text { EJP amplitudes, Ca }{ }^{2+} \text { imaging }\end{array}$ & [143] \\
\hline
\end{tabular}

\subsection{Ataxia Telangiectasia $(A-T)$}

Mutations in the human Ataxia Telangiectasia Mutated (ATM) gene lead to a variety of pathologies, including increased risk of certain cancers, increased risk of infections, problems with motor control, and neurodegeneration [154]. ATM encodes an atypical protein kinase involved in the repair of double strand DNA breaks. The Drosophila homolog of ATM has several names, including dATM and tefu (telomere fusion) and was used to model the disease (Table 5). Similar to human patients, Drosophila carrying $d A T M / t e f u$ mutations exhibit neurodegeneration. Furthermore, analysis of dATM/tefu function in Drosophila has provided critical insights into the mechanisms underlying neurodegeneration in A-T patients. Specifically, loss of kinase activity in glial cells was shown to lead to activation of the innate immune response and the death of both glia and neurons [155,156]. Furthermore, because activation of the innate immune response has been linked to neurodegeneration in multiple contexts $[90,93,157,158]$, the Drosophila studies support the idea of a shared neurodegenerative mechanism underlying multiple disorders, including A-T and AD. More recently, the Drosophila model of A-T has been used to screen 2400 compounds for possible A-T therapeutics. These studies identified 10 lead compounds, including one that provided additional insights into the cellular mechanisms underlying A-T pathologies [159]. 
Table 5. Drosophila models of Ataxia Telangiectasia.

\begin{tabular}{|c|c|c|c|}
\hline \multicolumn{4}{|c|}{ Ataxia Telangiectasia } \\
\hline Drosophila Model & Developmental Stage & Assay Used for Neuropathology & References \\
\hline \multicolumn{4}{|c|}{ Drosophila orthologs of human genes } \\
\hline $\begin{array}{l}\text { ATM }^{8} \text { mutants and } \\
\text { knockdown of ATM }\end{array}$ & Adult & $\begin{array}{l}\text { Climbing assay, lifespan, histological } \\
\text { staining for vacuole quantification, } \\
\text { immunostaining with anti-Casp } \\
\text { prevalence of apoptosis }\end{array}$ & [155] \\
\hline $\begin{array}{l}\text { ATM }^{8} \text { mutants and } \\
\text { knockdown of ATM }\end{array}$ & Adult & $\begin{array}{l}\text { Concurrent climbing assay, lifespan, } \\
\text { histological staining for vacuole } \\
\text { quantification, immunostaining with } \\
\text { anti-Casp }{ }^{\text {Act }} \text { for prevalence of apoptosis }\end{array}$ & [156] \\
\hline $\begin{array}{c}\mathrm{ATM}^{3}, \mathrm{ATM}^{4}, \\
\text { and } \mathrm{ATM}^{8} \text { mutants }\end{array}$ & Adult & Percent eclosion, lifespan & [159] \\
\hline
\end{tabular}

\subsection{Mitochondrial Gene Mutations and Neurodegeneration}

Mitochondrial dysfunction has long been associated with neurodegenerative diseases (reviewed in [160]). AD, PD, and HD, among others, are all known to be potentiated by defects in mitochondrial dynamics. This is perhaps not surprising when one considers that neurons have extremely high energy requirements [161]. More recently, forward genetic screens in Drosophila have been used to identify genes that are so critical to mitochondrial function in neurons that their mutation leads to neurodegeneration, even in the absence of other predisposing mutations (Table 6). We describe two examples here.

In 2017, the Bellen laboratory reported that mutations in Nardilysin (dNRD1) were defective in the folding of the mitochondrial enzyme $\alpha$-ketoglutarate dehydrogenase, which is a rate-limiting enzyme for the Krebs Cycle [162]. The same group had previously shown that mutations in $d N R D 1$ led to neurodegeneration in the Drosophila retina [163]. Upon further investigation, mutations in $d N R D 1$ were found to lead to increased levels of $\alpha$-ketoglutarate which impaired autophagy via an increase in mTORC1 activity [162]. The work was important both because it offered a molecular mechanism for the neurodegeneration observed in the mutants and a potential therapeutic target $-\mathrm{mTORC} 1-$ for neurodegenerative disorders caused or enhanced by mutations in $A N R D 1$. Indeed, rapamycin was shown to alleviate the neurodegeneration caused by loss of either $d N R D 1$ or OGDH mutations [162], providing a clear proof of principle for the approach. We note, however, that because mTORC1 exerts pleiotropic effects, it may not be an ideal target for neurodegeneration therapeutics.

In 2018, the Ganetzky laboratory reported on the identification of a new allele of the nuclear-encoded mitochondrial Complex I enzyme, ND23 [21]. Drosophila ND23 mutations cause progressive neurodegeneration and early death. Another Complex 1 protein, NDUFS8, previously had been implicated in a human disorder called Leigh Syndrome [164]. Leigh Syndrome manifestations include early, progressive neurodegeneration with loss of cognitive and motor function. A confusing aspect of Leigh Syndrome has been the variation in phenotype among patients carrying the identical mutant alleles of NDUFS8. Loewen and Ganetzky now offer both a Drosophila model for Leigh Syndrome and an explanation for Leigh Syndrome phenotypic variability. In particular, they found that the mitochondrial genotype modifies the severity of the neurodegeneration in ND23 mutants and identified a mutation in the mitochondrially encoded ATPase 6 as a strong candidate enhancer of ND23 mutations [21]. Like ND23 and NDUFS8, ATPase 6 is a component of Complex I. Another Complex I mutation in the Drosophila gene ND75, homolog of human NDUFS1, has been shown to contribute to neurodegeneration [165]. The work underscores the utility of Drosophila for understanding neurodegenerative disorders and provides a model for the testing of potential therapeutics. 
Table 6. Drosophila models of neurodegenerative mitochondrial gene mutations.

\begin{tabular}{cccc}
\hline Drosophila Model & $\begin{array}{c}\text { Mitochondrial Gene Mutations and Neurodegeneration } \\
\text { Developmental Stage } \\
\text { Drosophila orthologs of human genes }\end{array}$ & References \\
\hline ND23 mutants & Adult & $\begin{array}{c}\text { Climbing assay, bang-sensitivity assay, } \\
\text { lifespan, histological staining for } \\
\text { vacuole quantification }\end{array}$ & {$[21]$} \\
\hline $\begin{array}{l}\text { dNRD1 mutants, OGDH } \\
\text { mutants, and knockdown }\end{array}$ & Adult & $\begin{array}{c}\text { Electroretinogram recordings for } \\
\text { neuronal function, histology for } \\
\text { retinal morphology }\end{array}$ & {$[162]$} \\
\hline ND75 knockdown & Adult & $\begin{array}{c}\text { Lifespan, climbing assay, histological } \\
\text { staining for vacuole quantification, } \\
\text { immunostaining for cleaved PARP to } \\
\text { quantify caspase activity }\end{array}$ & {$[165]$} \\
\hline
\end{tabular}

\subsection{The Brain Tumor Gene and Neurodegeneration}

A novel genetic model for neurodegeneration recently was described in Drosophila [166] (Table 7). This model consists of a new mutation in the TRIM-NHL (tripartite motif-NCL-1, HT2A, and LIN-41) protein encoded by the Drosophila brain tumor (brat) gene. Mutations in human TRIM proteins have been associated with neuropathologies, including AD [167] and axonal neuropathy [168]. However, the new mutation, brat $t^{\text {cheesehead }}$ ( rrat $^{\text {chs }}$ ), is unusual in leading to both brain tumors and progressive neurodegeneration. While deletions of TRIM3 frequently are found in primary human gliomas [169], the simultaneous presence of neurodegeneration and overgrowth is rare and raises the intriguing question of whether one leads to the other. Epidemiological studies have identified positive associations between PD and an increased risk of malignant brain tumors [170,171], while genetic studies have shown that mutations in the human E3-ubiquitin ligase-coding gene PARK2 are associated with several malignancies in addition to early onset PD [172]. Thus, it seems likely that rat $^{\text {chs }}$ flies may serve as an excellent model for identification of still unknown mechanisms underlying neurodegenerative diseases and for the testing of potential therapeutics.

Table 7. Drosophila model of a neurodegenerative brain tumor.

\begin{tabular}{|c|c|c|c|}
\hline \multicolumn{4}{|c|}{ Brain Tumor } \\
\hline Drosophila Model & Developmental Stage & Assay Used for Neuropathology & References \\
\hline \multicolumn{4}{|c|}{ Drosophila orthologs of human genes } \\
\hline $\begin{array}{l}\text { brat }^{\text {chs }} \text { mutant, brat } \\
\text { pchs; } \\
\text { pcna-GFP and brat } \\
\text { CG15864 } \\
\text { mutants }\end{array}$ & Adult & $\begin{array}{l}\text { Histological staining for vacuole } \\
\text { quantification, climbing assay, } \\
\text { immunostaining with anti-cleaved } \\
\text { Dcp-1 for prevalence of apoptosis }\end{array}$ & [166] \\
\hline
\end{tabular}

\subsection{Drosophila Traumatic Brain Injury and Neurodegeneration}

In 2013, the first Drosophila model of closed-head TBI was published by the Wassarman and Ganetzky laboratories [173] (Table 8). Similar to humans, TBI in Drosophila leads to temporary incapacitation, ataxia, innate immune response activation, neurodegeneration and death [173]. The neurodegeneration is analogous to the CTE observed in human TBI patients. Over the intervening seven years, much has been learned about the factors influencing in TBI outcomes in Drosophila. These factors include age and diet as well as genetic background [174,175]. Being able to study the mechanisms underlying neurodegeneration in controlled genetic backgrounds is extremely powerful and already providing insights into both genetic and environmental variables that can contribute to neurodegeneration or to neuroprotection.

The standard TBI protocol in Drosophila involves four impacts spaced at 5-minute intervals. A standard outcome measure is the percent of injured flies that die within the first $24 \mathrm{~h}$ following 
the injury. A survey of more than 200 "wild type" Drosophila strains derived from a single wild type population [176], revealed that post-TBI mortality is influenced tremendously by genetic background with some strains exhibiting as little as $10 \%$ mortality and others exhibiting $60 \%$ mortality [175]. Moreover, using mortality as a measure, TBI outcomes were found to be worse in older adults than in younger adults [174].

Notably, restricting food intake after TBI was shown to have beneficial effects, paralleling TBI outcomes in humans, where increased hyperglycemia (e.g., as seen in patients with diabetes) is linked to significantly increased risk of death after TBI [175]. These results suggest that the secondary injuries leading to organismal death are similar in Drosophila and humans and that further studies in Drosophila are likely to provide additional new information that will help us understand the complex consequences of TBI [175].

Gene expression studies have permitted the identification of genes that are up- or down-regulated following Drosophila TBI. The up-regulated genes include components of the Drosophila innate immune system [174], some of which previously have been linked to neurodegeneration in Drosophila [93,157]. This raises the possibility that pharmacological control of innate immunity programs in human patients could reduce secondary injuries and therefore prevent adverse TBI outcomes.

In recent years, the utility of this model has become sufficiently clear that other laboratories are now using it [177-182]. Because of the parallels between Drosophila and human responses to TBI, there are multiple future applications for this model. These include evaluating the utility of various drugs in treating TBI in the clinic [183]. Future applications of this work will include testing the efficacy of these same pharmaceutical agents in preventing genetically induced neurodegeneration. In addition, because TBI patients often require surgery, not only for the head injury but also for other injuries sustained in parallel, the Drosophila model should also prove useful for the safety of individual anesthetics for TBI patients [184].

Table 8. Drosophila models of neurodegenerative traumatic brain injury.

\begin{tabular}{cccc}
\hline Drosophila Model & Developmental Stage & Assay Used for Neuropathology & References \\
\hline $\begin{array}{c}\text { Injury from the High-Impact } \\
\text { Trauma device }\end{array}$ & Adult & $\begin{array}{c}\text { Lifespan, histological staining for } \\
\text { vacuole quantification }\end{array}$ & {$[173]$} \\
\hline $\begin{array}{c}\text { Stab injury to the brain } \\
\text { through the right eye }\end{array}$ & Adult & $\begin{array}{c}\text { Lifespan, climbing assay, } \\
\text { mobility assay }\end{array}$ & {$[183]$} \\
\hline
\end{tabular}

\section{Looking Ahead}

In summary, Drosophila are a powerful model in which to gain insights into human neurodegenerative disorders. Studies in Drosophila have made major contributions to our understanding of neurodegenerative disorders. For instance, the importance of mitochondria to PD was discovered in flies $[69,76,80]$, as was the toxicity of arginine-containing dipeptide repeats in ALS [107]. Candidates from human GWAS can also be readily validated in Drosophila, as shown in [39]. The availability of Drosophila models for diseases such as AD, PD, and HD provides opportunities for the discovery of molecular mechanisms that affect disease progression and tools for the identification of therapeutics. More recently, Drosophila have emerged as a model in which to study neural regeneration. A variety of models have been created, including several in which to investigate axon or dendrite regrowth after injury as well as an adult brain model for the simultaneous analysis of degeneration and regeneration after brain injury (Table 9). An important direction for future research will be to apply what we are learning about neural regeneration to the neurodegenerative disease models to test whether we can slow or reverse specific types of neurodegeneration. For instance, one could imagine using CRISPR/Cas9 to correct a genetic defect in a subset of cells within the brain and then activating those cells to replace neurons and/or glia that were lost or damaged. Using this type of approach, one might first pre-empt Lewy body formation in neural stem cells, then coax those same stem cells to replace 
lost dopaminergic neurons in a PD model. These types of experiments could be done in Drosophila, paving the way for future studies in mammalian models and human patients. Because of the shared developmental genetics of the Drosophila and human nervous systems, it seems likely that Drosophila will prove as fruitful for modeling neural regeneration as it has for modeling neural degeneration.

Table 9. Drosophila models of neuroregeneration.

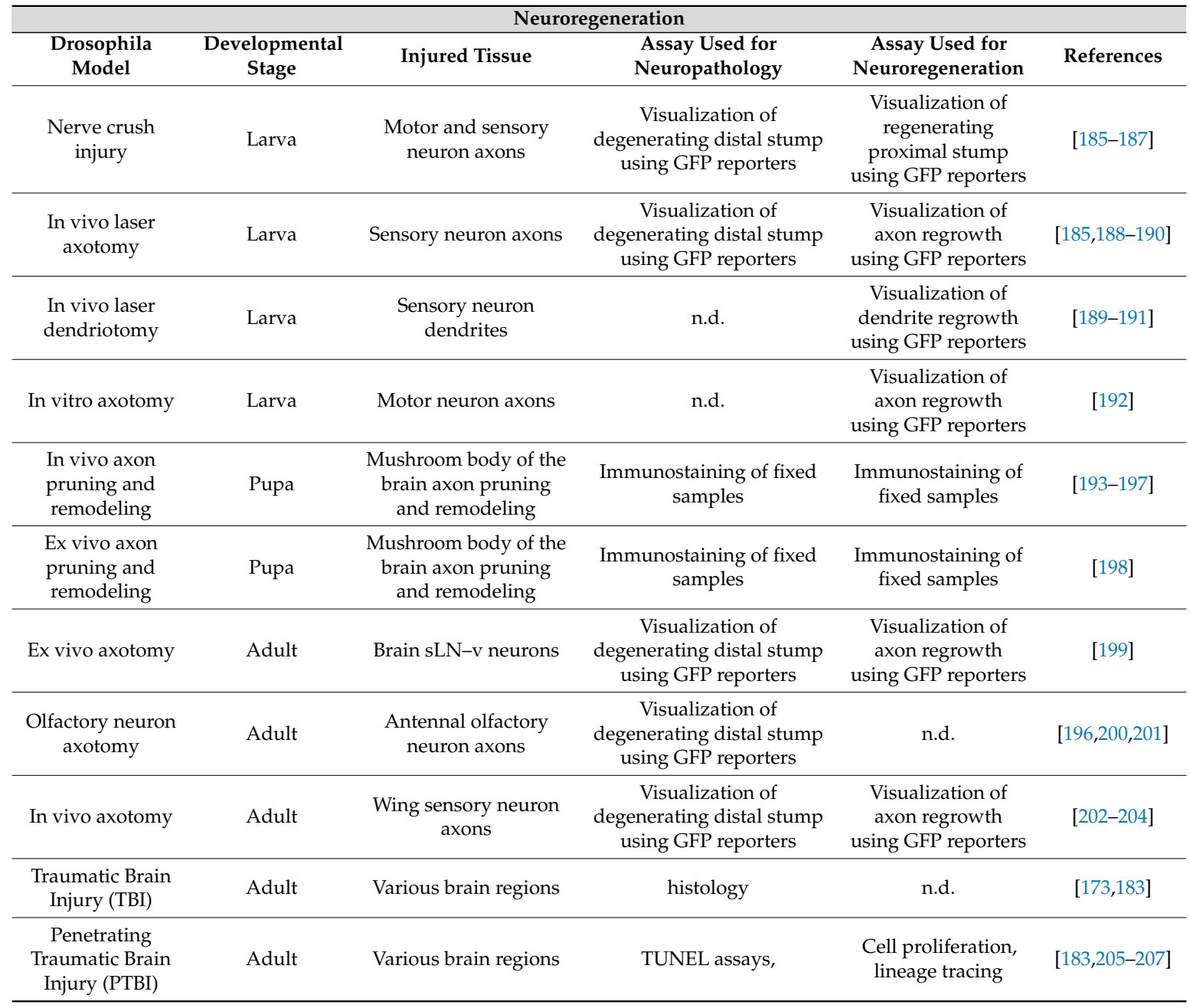

Acknowledgments: Due to space limitations: we could not be comprehensive in describing all existing Drosophila neurodegenerative disease models. We therefore apologize for omissions. We would like to thank the reviewers for their meticulous reding of the initial version of the manuscript. This work was supported by NIH T32 GM007133 (KLC); NIH NS102698 (GBF); start-up funds from the University of Alabama (SC), the Merrymac/McKinley Foundation (SC) and the Women in Science and Engineering Leadership Institute (WISELI) (GBF).

Conflicts of Interest: The authors declare no conflict of interest

\section{Definitions and Abbreviations}

$\mathrm{A} \beta$

$\mathrm{AD}$

ALS

APP

APPL

A-T

BACE

Cas9
Amyloid-beta

Alzheimer's Disease

Amyotrophic Lateral Sclerosis

Amyloid Precursor Protein

Amyloid-beta-like protein

Ataxia Telangiectasia

Beta-secretase

CRISPR Associated Protein 9 


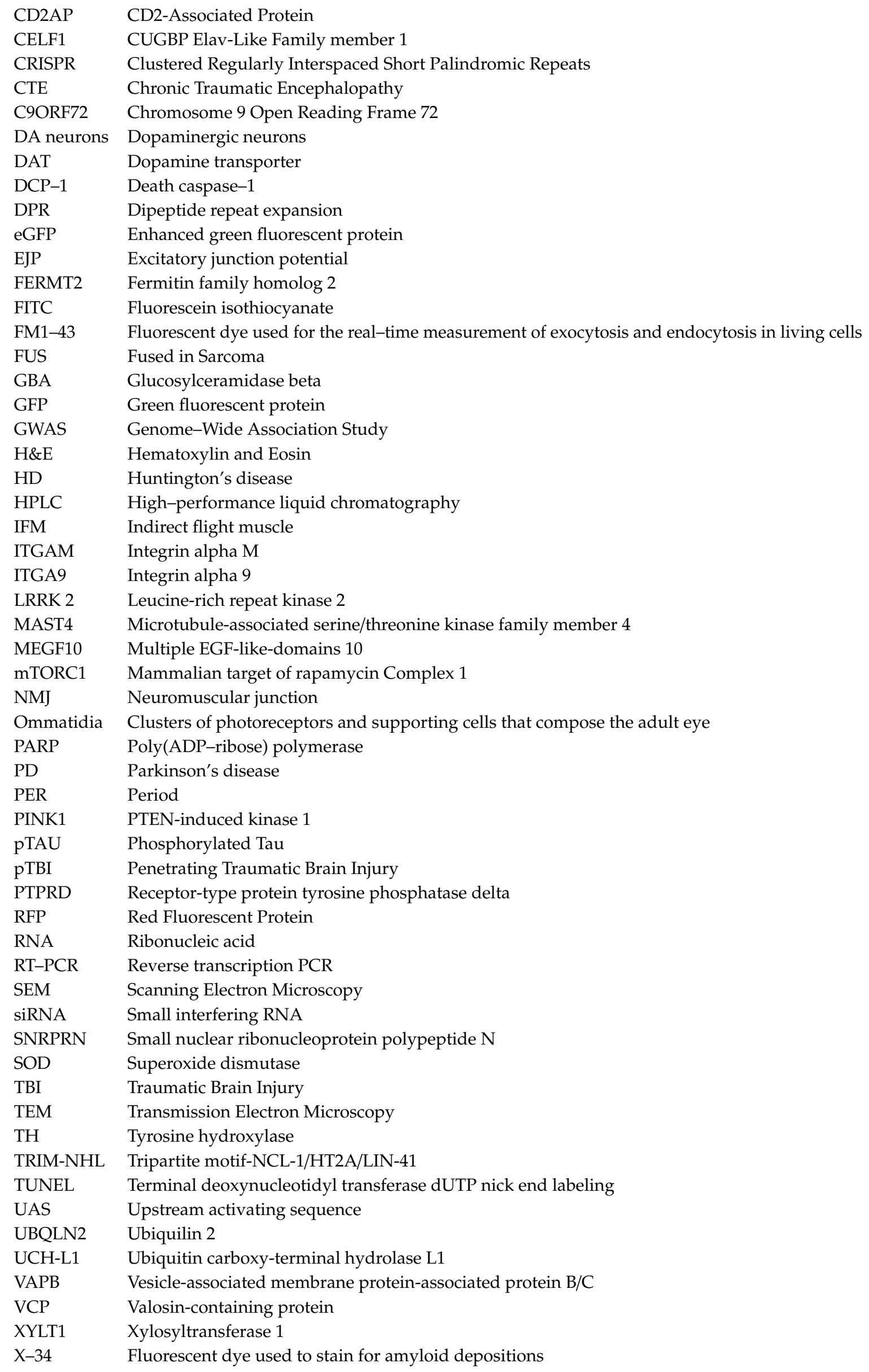




\section{References}

1. Venken:, K.J.; Simpson, J.H.; Bellen, H.J. Genetic manipulation of genes and cells in the nervous system of the fruit fly. Neuron 2011, 72, 202-230. [CrossRef] [PubMed]

2. Mohr, S.E.; Perrimon, N. Drosophila melanogaster: A simple system for understanding complexity. Dis. Model. Mech. 2019, 12. [CrossRef]

3. Yamaguchi, M. Drosophila Models for Human Diseases Preface. Adv. Exp. Med. Biol. 2018, 1076, V-Vi. [CrossRef]

4. Ugur, B.; Chen, K.; Bellen, H.J. Drosophila tools and assays for the study of human diseases. Dis. Model. Mech. 2016, 9, 235-244. [CrossRef] [PubMed]

5. Hirth, F. On the origin and evolution of the tripartite brain. Brain. Behav. Evol. 2010, 76, 3-10. [CrossRef] [PubMed]

6. Bier, E.; Vaessin, H.; Shepherd, S.; Lee, K.; McCall, K.; Barbel, S.; Ackerman, L.; Carretto, R.; Uemura, T.; Grell, E.; et al. Searching for pattern and mutation in the Drosophila genome with a P-lacZ vector. Gen. Dev. 1989, 3, 1273-1287. [CrossRef] [PubMed]

7. Xu, T.; Rebay, I.; Fleming, R.J.; Scottgale, T.N.; Artavanis-Tsakonas, S. The Notch locus and the genetic circuitry involved in early Drosophila neurogenesis. Gen. Dev. 1990, 4, 464-475. [CrossRef]

8. Thaker, H.M.; Kankel, D.R. Mosaic analysis gives an estimate of the extent of genomic involvement in the development of the visual system in Drosophila melanogaster. Genetics 1992, 131, 883-894.

9. Rottgen, G.; Wagner, T.; Hinz, U. A genetic screen for elements of the network that regulates neurogenesis in Drosophila. Mol. Gen. Genet. 1998, 257, 442-451. [CrossRef]

10. Brody, T.; Stivers, C.; Nagle, J.; Odenwald, W.F. Identification of novel Drosophila neural precursor genes using a differential embryonic head cDNA screen. Mech. Dev. 2002, 113, 41-59. [CrossRef]

11. Reuter, J.E.; Nardine, T.M.; Penton, A.; Billuart, P.; Scott, E.K.; Usui, T.; Uemura, T.; Luo, L. A mosaic genetic screen for genes necessary for Drosophila mushroom body neuronal morphogenesis. Development 2003, 130, 1203-1213. [CrossRef] [PubMed]

12. Laviolette, M.J.; Nunes, P.; Peyre, J.B.; Aigaki, T.; Stewart, B.A. A genetic screen for suppressors of Drosophila NSF2 neuromuscular junction overgrowth. Genetics 2005, 170, 779-792. [CrossRef] [PubMed]

13. Slack, C.; Somers, W.G.; Sousa-Nunes, R.; Chia, W.; Overton, P.M. A mosaic genetic screen for novel mutations affecting Drosophila neuroblast divisions. BMC Genet. 2006, 7, 33. [CrossRef]

14. Schuldiner, O.; Berdnik, D.; Levy, J.M.; Wu, J.S.; Luginbuhl, D.; Gontang, A.C.; Luo, L. piggyBac-based mosaic screen identifies a postmitotic function for cohesin in regulating developmental axon pruning. Dev. Cell 2008, 14, 227-238. [CrossRef]

15. Ou, Y.; Chwalla, B.; Landgraf, M.; van Meyel, D.J. Identification of genes influencing dendrite morphogenesis in developing peripheral sensory and central motor neurons. Neural Dev. 2008, 3, 16. [CrossRef]

16. Chen, D.; Gu, T.; Pham, T.N.; Zachary, M.J.; Hewes, R.S. Regulatory Mechanisms of Metamorphic Neuronal Remodeling Revealed Through a Genome-Wide Modifier Screen in Drosophila melanogaster. Genetics 2017, 206, 1429-1443. [CrossRef]

17. Goel, P.; Khan, M.; Howard, S.; Kim, G.; Kiragasi, B.; Kikuma, K.; Dickman, D. A Screen for Synaptic Growth Mutants Reveals Mechanisms That Stabilize Synaptic Strength. J. Neurosci. 2019, 39, 4051-4065. [CrossRef]

18. McGurk, L.; Berson, A.; Bonini, N.M. Drosophila as an In Vivo Model for Human Neurodegenerative Disease. Genetics 2015, 201, 377-402. [CrossRef]

19. Gevedon, O.; Bolus, H.; Lye, S.H.; Schmitz, K.; Fuentes-Gonzalez, J.; Hatchell, K.; Bley, L.; Pienaar, J.; Loewen, C.; Chtarbanova, S. In Vivo Forward Genetic Screen to Identify Novel Neuroprotective Genes in Drosophila melanogaster. J. Vis. Exp. 2019, 149. [CrossRef]

20. Greeve, I.; Kretzschmar, D.; Tschape, J.A.; Beyn, A.; Brellinger, C.; Schweizer, M.; Nitsch, R.M.; Reifegerste, R. Age-dependent neurodegeneration and Alzheimer-amyloid plaque formation in transgenic Drosophila. J. Neurosci. 2004, 24, 3899-3906. [CrossRef]

21. Loewen, C.A.; Ganetzky, B. Mito-Nuclear Interactions Affecting Lifespan and Neurodegeneration in a Drosophila Model of Leigh Syndrome. Genetics 2018, 208, 1535-1552. [CrossRef]

22. Rimkus, S.A.; Katzenberger, R.J.; Trinh, A.T.; Dodson, G.E.; Tibbetts, R.S.; Wassarman, D.A. Mutations in String/CDC25 inhibit cell cycle re-entry and neurodegeneration in a Drosophila model of Ataxia telangiectasia. Genes Dev. 2008, 22, 1205-1220. [CrossRef] 
23. Babcock, D.T.; Shen, W.; Ganetzky, B. A neuroprotective function of NSF1 sustains autophagy and lysosomal trafficking in Drosophila. Genetics 2015, 199, 511-522. [CrossRef]

24. Hanson, K.A.; Kim, S.H.; Wassarman, D.A.; Tibbetts, R.S. Ubiquilin modifies TDP-43 toxicity in a Drosophila model of amyotrophic lateral sclerosis (ALS). J. Biol. Chem. 2010, 285, 11068-11072. [CrossRef]

25. Babcock, D.T.; Ganetzky, B. Transcellular spreading of huntingtin aggregates in the Drosophila brain. Proc. Natl. Acad. Sci. USA 2015, 112, E5427-E5433. [CrossRef]

26. Alzheimer's Association. 2018 Alzheimer's disease facts and figures. Alzheimers Dement. 2018, 14, $367-429$. [CrossRef]

27. Fernandez-Funez, P.; de Mena, L.; Rincon-Limas, D.E. Modeling the complex pathology of Alzheimer's disease in Drosophila. Exp. Neurol. 2015, 274, 58-71. [CrossRef]

28. Ramos Bernardes da Silva Filho, S.; Oliveira Barbosa, J.H.; Rondinoni, C.; Dos Santos, A.C.; Garrido Salmon, C.E.; da Costa Lima, N.K.; Ferriolli, E.; Moriguti, J.C. Neuro-degeneration profile of Alzheimer's patients: A brain morphometry study. Neuroimage Clin. 2017, 15, 15-24. [CrossRef]

29. Hebert, L.E.; Weuve, J.; Scherr, P.A.; Evans, D.A. Alzheimer disease in the United States (2010-2050) estimated using the 2010 census. Neurology 2013, 80, 1778-1783. [CrossRef]

30. Heron, M. Deaths: Leading Causes for 2017. Nat. Vital Stat. Rep. 2019, 68.

31. Szeto, J.Y.; Lewis, S.J. Current Treatment Options for Alzheimer's Disease and Parkinson's Disease Dementia. Curr. Neuropharmacol. 2016, 14, 326-338. [CrossRef]

32. Morris, M.C.; Tangney, C.C.; Wang, Y.; Sacks, F.M.; Bennett, D.A.; Aggarwal, N.T. MIND diet associated with reduced incidence of Alzheimer's disease. Alzheimers Dement. 2015, 11, 1007-1014. [CrossRef]

33. De Strooper, B.; Annaert, W. Proteolytic processing and cell biological functions of the amyloid precursor protein. J. Cell. Sci. 2000, 113 Pt 11, 1857-1870.

34. O’Brien, R.J.; Wong, P.C. Amyloid precursor protein processing and Alzheimer's disease. Annu. Rev. Neurosci. 2011, 34, 185-204. [CrossRef]

35. Liu, P.P.; Xie, Y.; Meng, X.Y.; Kang, J.S. History and progress of hypotheses and clinical trials for Alzheimer's disease. Signal Transduct. Target Ther. 2019, 4, 29. [CrossRef]

36. Stephenson, J.; Nutma, E.; van der Valk, P.; Amor, S. Inflammation in CNS neurodegenerative diseases. Immunology 2018, 154, 204-219. [CrossRef]

37. Lye, S.H.; Chtarbanova, S. Drosophila as a Model to Study Brain Innate Immunity in Health and Disease. Int. J. Mol. Sci. 2018, 19, 3922. [CrossRef]

38. Ray, A.; Speese, S.D.; Logan, M.A. Glial Draper Rescues Abeta Toxicity in a Drosophila Model of Alzheimer's Disease. J. Neurosci. 2017, 37, 11881-11893. [CrossRef]

39. Shulman, J.M.; Imboywa, S.; Giagtzoglou, N.; Powers, M.P.; Hu, Y.; Devenport, D.; Chipendo, P.; Chibnik, L.B.; Diamond, A.; Perrimon, N.; et al. Functional screening in Drosophila identifies Alzheimer's disease susceptibility genes and implicates Tau-mediated mechanisms. Hum. Mol. Genet. 2014, 23, 870-877. [CrossRef]

40. Carmine-Simmen, K.; Proctor, T.; Tschape, J.; Poeck, B.; Triphan, T.; Strauss, R.; Kretzschmar, D. Neurotoxic effects induced by the Drosophila amyloid-beta peptide suggest a conserved toxic function. Neurobiol. Dis. 2009, 33, 274-281. [CrossRef]

41. Finelli, A.; Kelkar, A.; Song, H.J.; Yang, H.; Konsolaki, M. A model for studying Alzheimer's Abeta42-induced toxicity in Drosophila melanogaster. Mol. Cell. Neurosci. 2004, 26, 365-375. [CrossRef] [PubMed]

42. Crowther, D.C.; Kinghorn, K.J.; Miranda, E.; Page, R.; Curry, J.A.; Duthie, F.A.; Gubb, D.C.; Lomas, D.A. Intraneuronal Abeta, non-amyloid aggregates and neurodegeneration in a Drosophila model of Alzheimer's disease. Neuroscience 2005, 132, 123-135. [CrossRef] [PubMed]

43. Casas-Tinto, S.; Zhang, Y.; Sanchez-Garcia, J.; Gomez-Velazquez, M.; Rincon-Limas, D.E.; Fernandez-Funez, P. The ER stress factor XBP1s prevents amyloid-beta neurotoxicity. Hum. Mol. Genet. 2011, 20, 2144-2160. [CrossRef] [PubMed]

44. Tare, M.; Modi, R.M.; Nainaparampil, J.J.; Puli, O.R.; Bedi, S.; Fernandez-Funez, P.; Kango-Singh, M.; Singh, A. Activation of JNK signaling mediates amyloid-ss-dependent cell death. PLoS ONE 2011, 6, e24361. [CrossRef] [PubMed]

45. Luheshi, L.M.; Tartaglia, G.G.; Brorsson, A.C.; Pawar, A.P.; Watson, I.E.; Chiti, F.; Vendruscolo, M.; Lomas, D.A.; Dobson, C.M.; Crowther, D.C. Systematic in vivo analysis of the intrinsic determinants of amyloid Beta pathogenicity. PLoS Biol. 2007, 5, e290. [CrossRef] [PubMed] 
46. Brorsson, A.C.; Bolognesi, B.; Tartaglia, G.G.; Shammas, S.L.; Favrin, G.; Watson, I.; Lomas, D.A.; Chiti, F.; Vendruscolo, M.; Dobson, C.M.; et al. Intrinsic determinants of neurotoxic aggregate formation by the amyloid beta peptide. Biophys. J. 2010, 98, 1677-1684. [CrossRef]

47. Chiang, H.C.; Iijima, K.; Hakker, I.; Zhong, Y. Distinctive roles of different beta-amyloid 42 aggregates in modulation of synaptic functions. FASEB J. 2009, 23, 1969-1977. [CrossRef]

48. Kim, M.; Subramanian, M.; Cho, Y.H.; Kim, G.H.; Lee, E.; Park, J.J. Short-term exposure to dim light at night disrupts rhythmic behaviors and causes neurodegeneration in fly models of tauopathy and Alzheimer's disease. Biochem. Biophys. Res. Commun. 2018, 495, 1722-1729. [CrossRef]

49. Liu, B.; Moloney, A.; Meehan, S.; Morris, K.; Thomas, S.E.; Serpell, L.C.; Hider, R.; Marciniak, S.J.; Lomas, D.A.; Crowther, D.C. Iron promotes the toxicity of amyloid beta peptide by impeding its ordered aggregation. J. Biol. Chem. 2011, 286, 4248-4256. [CrossRef]

50. Hua, H.; Munter, L.; Harmeier, A.; Georgiev, O.; Multhaup, G.; Schaffner, W. Toxicity of Alzheimer's disease-associated Abeta peptide is ameliorated in a Drosophila model by tight control of zinc and copper availability. Biol. Chem. 2011, 392, 919-926. [CrossRef]

51. Sanokawa-Akakura, R.; Cao, W.; Allan, K.; Patel, K.; Ganesh, A.; Heiman, G.; Burke, R.; Kemp, F.W.; Bogden, J.D.; Camakaris, J.; et al. Control of Alzheimer's amyloid beta toxicity by the high molecular weight immunophilin FKBP52 and copper homeostasis in Drosophila. PLoS ONE 2010, 5, e8626. [CrossRef] [PubMed]

52. Rival, T.; Page, R.M.; Chandraratna, D.S.; Sendall, T.J.; Ryder, E.; Liu, B.; Lewis, H.; Rosahl, T.; Hider, R.; Camargo, L.M.; et al. Fenton chemistry and oxidative stress mediate the toxicity of the beta-amyloid peptide in a Drosophila model of Alzheimer's disease. Eur. J. Neurosci. 2009, 29, 1335-1347. [CrossRef]

53. Wolf, G.; Stahl, R.A. CD2-associated protein and glomerular disease. Lancet 2003, 362, 1746-1748. [CrossRef]

54. Lai-Cheong, J.E.; Parsons, M.; McGrath, J.A. The role of kindlins in cell biology and relevance to human disease. Int. J. Biochem. Cell. Biol. 2010, 42, 595-603. [CrossRef] [PubMed]

55. Chagnon, M.J.; Uetani, N.; Tremblay, M.L. Functional significance of the LAR receptor protein tyrosine phosphatase family in development and diseases. Biochem. Cell. Biol. 2004, 82, 664-675. [CrossRef]

56. Sarrazin, S.; Lamanna, W.C.; Esko, J.D. Heparan sulfate proteoglycans. Cold Spring Harb. Perspect. Biol. 2011, 3, a004952. [CrossRef]

57. Chakraborty, R.; Vepuri, V.; Mhatre, S.D.; Paddock, B.E.; Miller, S.; Michelson, S.J.; Delvadia, R.; Desai, A.; Vinokur, M.; Melicharek, D.J.; et al. Characterization of a Drosophila Alzheimer's disease model: Pharmacological rescue of cognitive defects. PLoS ONE 2011, 6, e20799. [CrossRef]

58. Mhatre, S.D.; Michelson, S.J.; Gomes, J.; Tabb, L.P.; Saunders, A.J.; Marenda, D.R. Development and characterization of an aged onset model of Alzheimer's disease in Drosophila melanogaster. Exp. Neurol. 2014, 261, 772-781. [CrossRef]

59. Walter, J.; Kaether, C.; Steiner, H.; Haass, C. The cell biology of Alzheimer's disease: Uncovering the secrets of secretases. Curr. Opin. Neurobiol. 2001, 11, 585-590. [CrossRef]

60. Esler, W.P.; Kimberly, W.T.; Ostaszewski, B.L.; Ye, W.; Diehl, T.S.; Selkoe, D.J.; Wolfe, M.S. Activity-dependent isolation of the presenilin- gamma -secretase complex reveals nicastrin and a gamma substrate. Proc. Natl. Acad. Sci. USA 2002, 99, 2720-2725. [CrossRef]

61. Francis, R.; McGrath, G.; Zhang, J.; Ruddy, D.A.; Sym, M.; Apfeld, J.; Nicoll, M.; Maxwell, M.; Hai, B.; Ellis, M.C.; et al. aph-1 and pen-2 are required for Notch pathway signaling, gamma-secretase cleavage of betaAPP, and presenilin protein accumulation. Dev. Cell 2002, 3, 85-97. [CrossRef]

62. Kozlowski, H.; Luczkowski, M.; Remelli, M.; Valensin, D. Copper, zinc and iron in neurodegenerative diseases (Alzheimer's, Parkinson's and prion diseases). Coordin. Chem. Rev. 2012, 256, 2129-2141. [CrossRef]

63. Xu, W.; Tan, L.; Wang, H.F.; Jiang, T.; Tan, M.S.; Tan, L.; Zhao, Q.F.; Li, J.Q.; Wang, J.; Yu, J.T. Meta-analysis of modifiable risk factors for Alzheimer's disease. J. Neurol. Neurosur. Ps. 2015, 86, 1299-1306. [CrossRef] [PubMed]

64. Luo, L.; Tully, T.; White, K. Human amyloid precursor protein ameliorates behavioral deficit of flies deleted for Appl gene. Neuron 1992, 9, 595-605. [CrossRef]

65. Marras, C.; Beck, J.C.; Bower, J.H.; Roberts, E.; Ritz, B.; Ross, G.W.; Abbott, R.D.; Savica, R.; Van Den Eeden, S.K.; Willis, A.W.; et al. Prevalence of Parkinson's disease across North America. NPJ Parkinsons Dis. 2018, 4, 21. [CrossRef] 
66. Galvan, A.; Wichmann, T. Pathophysiology of parkinsonism. Clin. Neurophysiol. 2008, 119, 1459-1474. [CrossRef]

67. Poewe, W.; Seppi, K.; Tanner, C.M.; Halliday, G.M.; Brundin, P.; Volkmann, J.; Schrag, A.E.; Lang, A.E. Parkinson disease. Nat. Rev. Dis. Primers 2017, 3, 17013. [CrossRef]

68. Witt, K.; Kalbe, E.; Erasmi, R.; Ebersbach, G. Nonpharmacological treatment procedures for Parkinson's disease. Nervenarzt 2017, 88, 383-390. [CrossRef]

69. Clark, I.E.; Dodson, M.W.; Jiang, C.G.; Cao, J.H.; Huh, J.R.; Seol, J.H.; Yoo, S.J.; Hay, B.A.; Guo, M. Drosophila pink1 is required for mitochondrial function and interacts genetically with parkin. Nature 2006, 441, 1162-1166. [CrossRef]

70. Feuillette, S.; Miguel, L.; Frebourg, T.; Campion, D.; Lecourtois, M. Drosophila models of human tauopathies indicate that Tau protein toxicity in vivo is mediated by soluble cytosolic phosphorylated forms of the protein. J. Neurochem. 2010, 113, 895-903. [CrossRef]

71. Lee, S.B.; Kim, W.; Lee, S.; Chung, J. Loss of LRRK2/PARK8 induces degeneration of dopaminergic neurons in Drosophila. Biochem. Biophys. Res. Commun. 2007, 358, 534-539. [CrossRef] [PubMed]

72. M'Angale, P.G.; Staveley, B.E. The HtrA2 Drosophila model of Parkinson's disease is suppressed by the pro-survival Bcl-2 Buffy. Genome 2017, 60, 1-7. [CrossRef] [PubMed]

73. Maor, G.; Cabasso, O.; Krivoruk, O.; Rodriguez, J.; Steller, H.; Segal, D.; Horowitz, M. The contribution of mutant GBA to the development of Parkinson disease in Drosophila. Hum. Mol. Genet. 2016, 25, 2712-2727. [CrossRef] [PubMed]

74. Meulener, M.; Whitworth, A.J.; Armstrong-Gold, C.E.; Rizzu, P.; Heutink, P.; Wes, P.D.; Pallanck, L.J.; Bonini, N.M. Drosophila DJ-1 mutants are selectively sensitive to environmental toxins associated with Parkinson's disease. Curr. Biol. 2005, 15, 1572-1577. [CrossRef]

75. Molina-Mateo, D.; Fuenzalida-Uribe, N.; Hidalgo, S.; Molina-Fernandez, C.; Abarca, J.; Zarate, R.V.; Escandon, M.; Figueroa, R.; Tevy, M.F.; Campusano, J.M. Characterization of a presymptomatic stage in a Drosophila Parkinson's disease model: Unveiling dopaminergic compensatory mechanisms. Biochim. Biophys. Acta. Mol. Basis. Dis. 2017, 1863, 2882-2890. [CrossRef]

76. Park, J.; Lee, S.B.; Lee, S.; Kim, Y.; Song, S.; Kim, S.; Bae, E.; Kim, J.; Shong, M.H.; Kim, J.M.; et al. Mitochondrial dysfunction in Drosophila PINK1 mutants is complemented by parkin. Nature 2006, 441, 1157-1161. [CrossRef]

77. Thao, D.T.P. Drosophila Model in the Study Role of UCH-L1, Drosophila melanogaster. In Model for Recent Advances in Genetics and Therapeutics; Perveen, F.K., Ed.; IntechOpen: London, UK, 2018. [CrossRef]

78. Whitworth, A.J.; Theodore, D.A.; Greene, J.C.; Benes, H.; Wes, P.D.; Pallanck, L.J. Increased glutathione S-transferase activity rescues dopaminergic neuron loss in a Drosophila model of Parkinson's disease. Proc. Natl. Acad. Sci. USA 2005, 102, 8024-8029. [CrossRef]

79. Yang, Y.; Nishimura, I.; Imai, Y.; Takahashi, R.; Lu, B. Parkin suppresses dopaminergic neuron-selective neurotoxicity induced by Pael-R in Drosophila. Neuron 2003, 37, 911-924. [CrossRef]

80. Yang, Y.F.; Gehrke, S.; Imai, Y.; Huang, Z.N.; Ouyang, Y.; Wang, J.W.; Yang, L.C.; Beal, M.F.; Vogel, H.; Lu, B.W. Mitochondrial pathology and muscle and dopaminergic neuron degeneration caused inactivation of Drosophila Pink1 is rescued by by Parkin. Proc. Natl. Acad. Sci. USA 2006, 103, 10793-10798. [CrossRef]

81. Feany, M.B.; Bender, W.W. A Drosophila model of Parkinson's disease. Nature 2000, 404, 394-398. [CrossRef]

82. Liu, Z.; Wang, X.; Yu, Y.; Li, X.; Wang, T.; Jiang, H.; Ren, Q.; Jiao, Y.; Sawa, A.; Moran, T.; et al. A Drosophila model for LRRK2-linked parkinsonism. Proc. Natl. Acad. Sci. USA 2008, 105, 2693-2698. [CrossRef]

83. Roy, B.; Jackson, G.R. Interactions between Tau and alpha-synuclein augment neurotoxicity in a Drosophila model of Parkinson's disease. Hum. Mol. Genet. 2014, 23, 3008-3023. [CrossRef]

84. Coulom, H.; Birman, S. Chronic exposure to rotenone models sporadic Parkinson's disease in Drosophila melanogaster. J. Neurosci. 2004, 24, 10993-10998. [CrossRef] [PubMed]

85. Shukla, A.K.; Ratnasekhar, C.; Pragya, P.; Chaouhan, H.S.; Patel, D.K.; Chowdhuri, D.K.; Mudiam, M.K.R. Metabolomic Analysis Provides Insights on Paraquat-Induced Parkinson-Like Symptoms in Drosophila melanogaster. Mol. Neurobiol. 2016, 53, 254-269. [CrossRef] [PubMed]

86. Chaudhuri, A.; Bowling, K.; Funderburk, C.; Lawal, H.; Inamdar, A.; Wang, Z.; O’Donnell, J.M. Interaction of genetic and environmental factors in a Drosophila parkinsonism model. J. Neurosci. 2007, 27, 2457-2467. [CrossRef] 
87. Mershin, A.; Pavlopoulos, E.; Fitch, O.; Braden, B.C.; Nanopoulos, D.V.; Skoulakis, E.M.C. Learning and memory deficits upon TAU accumulation in Drosophila mushroom body neurons. Learn. Memory 2004, 11, 277-287. [CrossRef] [PubMed]

88. Brand, A.H.; Perrimon, N. Targeted Gene-Expression as a Means of Altering Cell Fates and Generating Dominant Phenotypes. Development 1993, 118, 401-415.

89. Bardai, F.H.; Ordonez, D.G.; Bailey, R.M.; Hamm, M.; Lewis, J.; Feany, M.B. Lrrk promotes tau neurotoxicity through dysregulation of actin and mitochondrial dynamics. PLoS Biol. 2018, 16, e2006265. [CrossRef]

90. Maitra, U.; Scaglione, M.N.; Chtarbanova, S.; O'Donnell, J.M. Innate immune responses to paraquat exposure in a Drosophila model of Parkinson's disease. Sci. Rep. 2019, 9, 12714. [CrossRef]

91. Hunot, S.; Dugas, N.; Faucheux, B.; Hartmann, A.; Tardieu, M.; Debre, P.; Agid, Y.; Dugas, B.; Hirsch, E.C. Fc epsilon RII/CD23 is expressed in Parkinson's disease and induces, in vitro, production of nitric oxide and tumor necrosis factor-alpha in glial cells. J. Neurosci. 1999, 19, 3440-3447. [CrossRef]

92. Tansey, M.G.; Mccoy, M.K.; Frank-Cannon, T.C. Neuroinflammatory mechanisms in Parkinson's disease: Potential environmental triggers, pathways, and targets for early therapeutic intervention. Exp. Neurol. 2007, 208, 1-25. [CrossRef] [PubMed]

93. Cao, Y.; Chtarbanova, S.; Petersen, A.J.; Ganetzky, B. Dnr1 mutations cause neurodegeneration in Drosophila by activating the innate immune response in the brain. Proc. Natl. Acad. Sci. USA 2013, 110, E1752-E1760. [CrossRef] [PubMed]

94. Mackenzie, I.R.; Bigio, E.H.; Ince, P.G.; Geser, F.; Neumann, M.; Cairns, N.J.; Kwong, L.K.; Forman, M.S.; Ravits, J.; Stewart, H.; et al. Pathological TDP-43 distinguishes sporadic amyotrophic lateral sclerosis from amyotrophic lateral sclerosis with SOD1 mutations. Ann. Neurol. 2007, 61, 427-434. [CrossRef] [PubMed]

95. Vandal, S.E.; Zheng, X.; Ahmad, S.T. Molecular Genetics of Frontotemporal Dementia Elucidated by Drosophila Models-Defects in Endosomal(-)Lysosomal Pathway. Int. J. Mol. Sci. 2018, 19, 1714. [CrossRef]

96. Lanson, N.A., Jr.; Maltare, A.; King, H.; Smith, R.; Kim, J.H.; Taylor, J.P.; Lloyd, T.E.; Pandey, U.B. A Drosophila model of FUS-related neurodegeneration reveals genetic interaction between FUS and TDP-43. Hum. Mol. Genet. 2011, 20, 2510-2523. [CrossRef]

97. Wojcik, C.; Yano, M.; DeMartino, G.N. RNA interference of valosin-containing protein (VCP/p97) reveals multiple cellular roles linked to ubiquitin/proteasome-dependent proteolysis. J. Cell. Sci. 2004, 117, 281-292. [CrossRef]

98. Teuling, E.; Ahmed, S.; Haasdijk, E.; Demmers, J.; Steinmetz, M.O.; Akhmanova, A.; Jaarsma, D.; Hoogenraad, C.C. Motor neuron disease-associated mutant vesicle-associated membrane protein-associated protein (VAP) B recruits wild-type VAPs into endoplasmic reticulum-derived tubular aggregates. J. Neurosci. 2007, 27, 9801-9815. [CrossRef]

99. Tsuda, H.; Han, S.M.; Yang, Y.; Tong, C.; Lin, Y.Q.; Mohan, K.; Haueter, C.; Zoghbi, A.; Harati, Y.; Kwan, J.; et al. The amyotrophic lateral sclerosis 8 protein VAPB is cleaved, secreted, and acts as a ligand for Eph receptors. Cell 2008, 133, 963-977. [CrossRef]

100. Chen, H.J.; Anagnostou, G.; Chai, A.; Withers, J.; Morris, A.; Adhikaree, J.; Pennetta, G.; de Belleroche, J.S. Characterization of the Properties of a Novel Mutation in VAPB in Familial Amyotrophic Lateral Sclerosis. J. Biol. Chem. 2010, 285, 40266-40281. [CrossRef]

101. Han, S.M.; Tsuda, H.; Yang, Y.F.; Vibbert, J.; Cottee, P.; Lee, S.J.; Winek, J.; Haueter, C.; Bellen, H.J.; Miller, M.A. Secreted VAPB/ALS8 Major Sperm Protein Domains Modulate Mitochondrial Localization and Morphology via Growth Cone Guidance Receptors. Dev. Cell 2012, 22, 348-362. [CrossRef]

102. Chaplot, K.; Pimpale, L.; Ramalingam, B.; Deivasigamani, S.; Kamat, S.S.; Ratnaparkhi, G.S. SOD1 activity threshold and TOR signalling modulate VAP(P58S) aggregation via reactive oxygen species-induced proteasomal degradation in a Drosophila model of amyotrophic lateral sclerosis. Dis. Model. Mech. 2019, 12. [CrossRef]

103. Pennetta, G.; Hiesinger, P.R.; Fabian-Fine, R.; Meinertzhagen, I.A.; Bellen, H.J. Drosophila VAP-33A directs bouton formation at neuromuscular junctions in a dosage-dependent manner. Neuron 2002, 35, 291-306. [CrossRef]

104. Moens, T.G.; Mizielinska, S.; Niccoli, T.; Mitchell, J.S.; Thoeng, A.; Ridler, C.E.; Gronke, S.; Esser, J.; Heslegrave, A.; Zetterberg, H.; et al. Sense and antisense RNA are not toxic in Drosophila models of C9orf72-associated ALS/FTD. Acta Neuropathol. 2018, 135, 445-457. [CrossRef] [PubMed] 
105. Xu, Z.; Poidevin, M.; Li, X.; Li, Y.; Shu, L.; Nelson, D.L.; Li, H.; Hales, C.M.; Gearing, M.; Wingo, T.S.; et al. Expanded GGGGCC repeat RNA associated with amyotrophic lateral sclerosis and frontotemporal dementia causes neurodegeneration. Proc. Natl. Acad. Sci. USA 2013, 110, 7778-7783. [CrossRef] [PubMed]

106. Burguete, A.S.; Almeida, S.; Gao, F.B.; Kalb, R.; Akins, M.R.; Bonini, N.M. GGGGCC microsatellite RNA is neuritically localized, induces branching defects, and perturbs transport granule function. eLife 2015, 4, e08881. [CrossRef] [PubMed]

107. Mizielinska, S.; Gronke, S.; Niccoli, T.; Ridler, C.E.; Clayton, E.L.; Devoy, A.; Moens, T.; Norona, F.E.; Woollacott, I.O.C.; Pietrzyk, J.; et al. C9orf72 repeat expansions cause neurodegeneration in Drosophila through arginine-rich proteins. Science 2014, 345, 1192-1194. [CrossRef]

108. Zhang, X.; Gui, L.; Zhang, X.; Bulfer, S.L.; Sanghez, V.; Wong, D.E.; Lee, Y.; Lehmann, L.; Lee, J.S.; Shih, P.Y.; et al. Altered cofactor regulation with disease-associated p97/VCP mutations. Proc. Natl. Acad. Sci. USA 2015, 112, E1705-E1714. [CrossRef]

109. Freibaum, B.D.; Lu, Y.; Lopez-Gonzalez, R.; Kim, N.C.; Almeida, S.; Lee, K.H.; Badders, N.; Valentine, M.; Miller, B.L.; Wong, P.C.; et al. GGGGCC repeat expansion in C9orf72 compromises nucleocytoplasmic transport. Nature 2015, 525, 129-133. [CrossRef]

110. Tran, H.; Almeida, S.; Moore, J.; Gendron, T.F.; Chalasani, U.; Lu, Y.; Du, X.; Nickerson, J.A.; Petrucelli, L.; Weng, Z.; et al. Differential Toxicity of Nuclear RNA Foci versus Dipeptide Repeat Proteins in a Drosophila Model of C9ORF72 FTD/ALS. Neuron 2015, 87, 1207-1214. [CrossRef]

111. Zhang, K.; Donnelly, C.J.; Haeusler, A.R.; Grima, J.C.; Machamer, J.B.; Steinwald, P.; Daley, E.L.; Miller, S.J.; Cunningham, K.M.; Vidensky, S.; et al. The C9orf72 repeat expansion disrupts nucleocytoplasmic transport. Nature 2015, 525, 56-61. [CrossRef]

112. Lin, M.J.; Cheng, C.W.; Shen, C.K. Neuronal function and dysfunction of Drosophila dTDP. PLoS ONE 2011, 6, e20371. [CrossRef] [PubMed]

113. Voigt, A.; Herholz, D.; Fiesel, F.C.; Kaur, K.; Muller, D.; Karsten, P.; Weber, S.S.; Kahle, P.J.; Marquardt, T.; Schulz, J.B. TDP-43-mediated neuron loss in vivo requires RNA-binding activity. PLoS ONE 2010, 5, e12247. [CrossRef] [PubMed]

114. Estes, P.S.; Boehringer, A.; Zwick, R.; Tang, J.E.; Grigsby, B.; Zarnescu, D.C. Wild-type and A315T mutant TDP-43 exert differential neurotoxicity in a Drosophila model of ALS. Hum. Mol. Genet. 2011, 20, 2308-2321. [CrossRef] [PubMed]

115. Gregory, J.M.; Barros, T.P.; Meehan, S.; Dobson, C.M.; Luheshi, L.M. The aggregation and neurotoxicity of TDP-43 and its ALS-associated $25 \mathrm{kDa}$ fragment are differentially affected by molecular chaperones in Drosophila. PLoS ONE 2012, 7, e31899. [CrossRef]

116. Dormann, D.; Madl, T.; Valori, C.F.; Bentmann, E.; Tahirovic, S.; Abou-Ajram, C.; Kremmer, E.; Ansorge, O.; Mackenzie, I.R.; Neumann, M.; et al. Arginine methylation next to the PY-NLS modulates Transportin binding and nuclear import of FUS. EMBO J. 2012, 31, 4258-4275. [CrossRef]

117. Jackel, S.; Summerer, A.K.; Thommes, C.M.; Pan, X.; Voigt, A.; Schulz, J.B.; Rasse, T.M.; Dormann, D.; Haass, C.; Kahle, P.J. Nuclear import factor transportin and arginine methyltransferase 1 modify FUS neurotoxicity in Drosophila. Neurobiol. Dis. 2015, 74, 76-88. [CrossRef]

118. Scaramuzzino, C.; Monaghan, J.; Milioto, C.; Lanson, N.A., Jr.; Maltare, A.; Aggarwal, T.; Casci, I.; Fackelmayer, F.O.; Pennuto, M.; Pandey, U.B. Protein arginine methyltransferase 1 and 8 interact with FUS to modify its sub-cellular distribution and toxicity in vitro and in vivo. PLoS ONE 2013, 8, e61576. [CrossRef]

119. Daigle, J.G.; Lanson, N.A., Jr.; Smith, R.B.; Casci, I.; Maltare, A.; Monaghan, J.; Nichols, C.D.; Kryndushkin, D.; Shewmaker, F.; Pandey, U.B. RNA-binding ability of FUS regulates neurodegeneration, cytoplasmic mislocalization and incorporation into stress granules associated with FUS carrying ALS-linked mutations. Hum. Mol. Genet. 2013, 22, 1193-1205. [CrossRef]

120. Gonzalez-Perez, P.; Lu, Y.; Chian, R.J.; Sapp, P.C.; Tanzi, R.E.; Bertram, L.; McKenna-Yasek, D.; Gao, F.B.; Brown, R.H., Jr. Association of UBQLN1 mutation with Brown-Vialetto-Van Laere syndrome but not typical ALS. Neurobiol. Dis. 2012, 48, 391-398. [CrossRef]

121. Kim, S.H.; Stiles, S.G.; Feichtmeier, J.M.; Ramesh, N.; Zhan, L.; Scalf, M.A.; Smith, L.M.; Pandey, U.B.; Tibbetts, R.S. Mutation-dependent aggregation and toxicity in a Drosophila model for UBQLN2-associated ALS. Hum. Mol. Genet. 2018, 27, 322-337. [CrossRef] 
122. Chai, A.; Withers, J.; Koh, Y.H.; Parry, K.; Bao, H.; Zhang, B.; Budnik, V.; Pennetta, G. hVAPB, the causative gene of a heterogeneous group of motor neuron diseases in humans, is functionally interchangeable with its Drosophila homologue DVAP-33A at the neuromuscular junction. Hum. Mol. Genet. 2008, 17, 266-280. [CrossRef]

123. Watson, M.R.; Lagow, R.D.; Xu, K.; Zhang, B.; Bonini, N.M. A drosophila model for amyotrophic lateral sclerosis reveals motor neuron damage by human SOD1. J. Biol. Chem. 2008, 283, 24972-24981. [CrossRef] [PubMed]

124. Casci, I.; Pandey, U.B. A fruitful endeavor: Modeling ALS in the fruit fly. Brain Res. 2015, 1607, 47-74. [CrossRef] [PubMed]

125. Majounie, E.; Renton, A.E.; Mok, K.; Dopper, E.G.; Waite, A.; Rollinson, S.; Chio, A.; Restagno, G.; Nicolaou, N.; Simon-Sanchez, J.; et al. Frequency of the C9orf72 hexanucleotide repeat expansion in patients with amyotrophic lateral sclerosis and frontotemporal dementia: A cross-sectional study. Lancet Neurol. 2012, 11, 323-330. [CrossRef]

126. Edbauer, D.; Haass, C. An amyloid-like cascade hypothesis for C9orf72 ALS/FTD. Curr. Opin. Neurobiol. 2016, 36, 99-106. [CrossRef] [PubMed]

127. Kearse, M.G.; Todd, P.K. Repeat-associated non-AUG translation and its impact in neurodegenerative disease. Neurotherapeutics 2014, 11, 721-731. [CrossRef] [PubMed]

128. Gao, F.B.; Richter, J.D.; Cleveland, D.W. Rethinking Unconventional Translation in Neurodegeneration. Cell 2017, 171, 994-1000. [CrossRef]

129. Lee, Y.B.; Chen, H.J.; Peres, J.N.; Gomez-Deza, J.; Attig, J.; Stalekar, M.; Troakes, C.; Nishimura, A.L.; Scotter, E.L.; Vance, C.; et al. Hexanucleotide repeats in ALS/FTD form length-dependent RNA foci, sequester RNA binding proteins, and are neurotoxic. Cell Rep. 2013, 5, 1178-1186. [CrossRef]

130. Ohki, Y.; Wenninger-Weinzierl, A.; Hruscha, A.; Asakawa, K.; Kawakami, K.; Haass, C.; Edbauer, D.; Schmid, B. Glycine-alanine dipeptide repeat protein contributes to toxicity in a zebrafish model of C9orf72 associated neurodegeneration. Mol. Neurodegener. 2017, 12, 6. [CrossRef]

131. Goodman, L.D.; Prudencio, M.; Kramer, N.J.; Martinez-Ramirez, L.F.; Srinivasan, A.R.; Lan, M.; Parisi, M.J.; Zhu, Y.; Chew, J.; Cook, C.N.; et al. Toxic expanded GGGGCC repeat transcription is mediated by the PAF1 complex in C9orf72-associated FTD. Nat. Neurosci. 2019, 22, 863-874. [CrossRef]

132. Goodman, L.D.; Prudencio, M.; Srinivasan, A.R.; Rifai, O.M.; Lee, V.M.; Petrucelli, L.; Bonini, N.M. eIF4B and eIF4H mediate GR production from expanded G4C2 in a Drosophila model for C9orf72-associated ALS. Acta Neuropathol. Commun. 2019, 7, 62. [CrossRef] [PubMed]

133. Yuva-Aydemir, Y.; Almeida, S.; Krishnan, G.; Gendron, T.F.; Gao, F.B. Transcription elongation factor AFF2/FMR2 regulates expression of expanded GGGGCC repeat-containing C9ORF72 allele in ALS/FTD. Nat. Commun. 2019, 10, 5466. [CrossRef]

134. Couly, S.; Khalil, B.; Viguier, V.; Roussel, J.; Maurice, T.; Lievens, J.C. Sigma-1 receptor is a key genetic modulator in amyotrophic lateral sclerosis. Hum. Mol. Genet. 2020, 29, 529-540. [CrossRef] [PubMed]

135. Berson, A.; Goodman, L.D.; Sartoris, A.N.; Otte, C.G.; Aykit, J.A.; Lee, V.M.; Trojanowski, J.Q.; Bonini, N.M. Drosophila Ref1/ALYREF regulates transcription and toxicity associated with ALS/FTD disease etiologies. Acta Neuropathol. Commun. 2019, 7, 65. [CrossRef] [PubMed]

136. Zhang, C.; Yang, Y.; Liang, W.; Wang, T.; Wang, S.; Wang, X.; Wang, Y.; Jiang, H.; Feng, H. Neuroprotection by urate on the mutant hSOD1-related cellular and Drosophila models of amyotrophic lateral sclerosis: Implication for GSH synthesis via activating Akt/GSK3beta/Nrf2/GCLC pathways. Brain Res. Bull. 2019, 146, 287-301. [CrossRef] [PubMed]

137. Macdonald, M.E.; Ambrose, C.M.; Duyao, M.P.; Myers, R.H.; Lin, C.; Srinidhi, L.; Barnes, G.; Taylor, S.A.; James, M.; Groot, N.; et al. A Novel Gene Containing a Trinucleotide Repeat That Is Expanded and Unstable on Huntingtons-Disease Chromosomes. Cell 1993, 72, 971-983. [CrossRef]

138. Rubinsztein, D.C.; Leggo, J.; Coles, R.; Almqvist, E.; Biancalana, V.; Cassiman, J.J.; Chotai, K.; Connarty, M.; Crauford, D.; Curtis, A.; et al. Phenotypic characterization of individuals with 30-40 CAG repeats in the Huntington disease (HD) gene reveals HD cases with 36 repeats and apparently normal elderly individuals with 36-39 repeats. Am. J. Hum. Genet. 1996, 59, 16-22.

139. Roos, R.A. Huntington's disease: A clinical review. Orphanet J. Rare Dis. 2010, 5, 40. [CrossRef]

140. Pringsheim, T.; Wiltshire, K.; Day, L.; Dykeman, J.; Steeves, T.; Jette, N. The incidence and prevalence of Huntington's disease: A systematic review and meta-analysis. Mov. Disord. 2012, 27, 1083-1091. [CrossRef] 
141. Rosas-Arellano, A.; Estrada-Mondragon, A.; Pina, R.; Mantellero, C.A.; Castro, M.A. The Tiny Drosophila Melanogaster for the Biggest Answers in Huntington's Disease. Int. J. Mol. Sci 2018, 19, 2398. [CrossRef]

142. Krench, M.; Littleton, J.T. Modeling Huntington disease in Drosophila: Insights into axonal transport defects and modifiers of toxicity. Fly (Austin) 2013, 7, 229-236. [CrossRef] [PubMed]

143. Romero, E.; Cha, G.H.; Verstreken, P.; Ly, C.V.; Hughes, R.E.; Bellen, H.J.; Botas, J. Suppression of neurodegeneration and increased neurotransmission caused by expanded full-length huntingtin accumulating in the cytoplasm. Neuron 2008, 57, 27-40. [CrossRef] [PubMed]

144. Steffan, J.S.; Bodai, L.; Pallos, J.; Poelman, M.; McCampbell, A.; Apostol, B.L.; Kazantsev, A.; Schmidt, E.; Zhu, Y.Z.; Greenwald, M.; et al. Histone deacetylase inhibitors arrest polyglutamine-dependent neurodegeneration in Drosophila. Nature 2001, 413, 739-743. [CrossRef] [PubMed]

145. Xu, F.; Kula-Eversole, E.; Iwanaszko, M.; Hutchison, A.L.; Dinner, A.; Allada, R. Circadian Clocks Function in Concert with Heat Shock Organizing Protein to Modulate Mutant Huntingtin Aggregation and Toxicity. Cell Rep. 2019, 27, 59-70. [CrossRef]

146. Joshi, A.S.; Singh, V.; Gahane, A.; Thakur, A.K. Biodegradable Nanoparticles Containing Mechanism Based Peptide Inhibitors Reduce Polyglutamine Aggregation in Cell Models and Alleviate Motor Symptoms in a Drosophila Model of Huntington's Disease. ACS Chem. Neurosci. 2019, 10, 1603-1614. [CrossRef]

147. Karpuj, M.V.; Becher, M.W.; Springer, J.E.; Chabas, D.; Youssef, S.; Pedotti, R.; Mitchell, D.; Steinman, L. Prolonged survival and decreased abnormal movements in transgenic model of Huntington disease, with administration of the transglutaminase inhibitor cystamine. Nat. Med. 2002, 8, 143-149. [CrossRef]

148. Zhu, Y.; Li, C.; Tao, X.; Brazill, J.M.; Park, J.; Diaz-Perez, Z.; Zhai, R.G. Nmnat restores neuronal integrity by neutralizing mutant Huntingtin aggregate-induced progressive toxicity. Proc. Natl. Acad. Sci. USA 2019, 116, 19165-19175. [CrossRef]

149. Leng, Y.; Musiek, E.S.; Hu, K.; Cappuccio, F.P.; Yaffe, K. Association between circadian rhythms and neurodegenerative diseases. Lancet Neurol. 2019, 18, 307-318. [CrossRef]

150. Hood, S.; Amir, S. Neurodegeneration and the Circadian Clock. Front. Aging Neurosci. 2017, 9, 170. [CrossRef]

151. Apostol, B.L.; Kazantsev, A.; Raffioni, S.; Illes, K.; Pallos, J.; Bodai, L.; Slepko, N.; Bear, J.E.; Gertler, F.B.; Hersch, S.; et al. A cell-based assay for aggregation inhibitors as therapeutics of polyglutamine-repeat disease and validation in Drosophila. Proc. Natl. Acad. Sci. USA 2003, 100, 5950-5955. [CrossRef]

152. Kazantsev, A.; Walker, H.A.; Slepko, N.; Bear, J.E.; Preisinger, E.; Steffan, J.S.; Zhu, Y.Z.; Gertler, F.B.; Housman, D.E.; Marsh, J.L.; et al. A bivalent Huntingtin binding peptide suppresses polyglutamine aggregation and pathogenesis in Drosophila. Nat. Genet. 2002, 30, 367-376. [CrossRef]

153. Kazemi-Esfarjani, P.; Benzer, S. Genetic suppression of polyglutamine toxicity in Drosophila. Science 2000, 287, 1837-1840. [CrossRef]

154. Choy, K.R.; Watters, D.J. Neurodegeneration in ataxia-telangiectasia: Multiple roles of ATM kinase in cellular homeostasis. Dev. Dyn. 2018, 247, 33-46. [CrossRef] [PubMed]

155. Petersen, A.J.; Rimkus, S.A.; Wassarman, D.A. ATM kinase inhibition in glial cells activates the innate immune response and causes neurodegeneration in Drosophila. Proc. Natl. Acad. Sci. USA 2012, 109, E656-E664. [CrossRef] [PubMed]

156. Petersen, A.J.; Katzenberger, R.J.; Wassarman, D.A. The innate immune response transcription factor relish is necessary for neurodegeneration in a Drosophila model of ataxia-telangiectasia. Genetics 2013, 194, 133-142. [CrossRef] [PubMed]

157. Kounatidis, I.; Chtarbanova, S.; Cao, Y.; Hayne, M.; Jayanth, D.; Ganetzky, B.; Ligoxygakis, P. NF-kappaB Immunity in the Brain Determines Fly Lifespan in Healthy Aging and Age-Related Neurodegeneration. Cell Rep. 2017, 19, 836-848. [CrossRef] [PubMed]

158. Shukla, A.K.; Spurrier, J.; Kuzina, I.; Giniger, E. Hyperactive Innate Immunity Causes Degeneration of Dopamine Neurons upon Altering Activity of Cdk5. Cell Rep. 2019, 26, 131-144. [CrossRef]

159. Rimkus, S.A.; Wassarman, D.A. A pharmacological screen for compounds that rescue the developmental lethality of a Drosophila ATM mutant. PLoS ONE 2018, 13, e0190821. [CrossRef]

160. Chen, H.C.; Chan, D.C. Mitochondrial dynamics-fusion, fission, movement, and mitophagy-in neurodegenerative diseases. Hum. Mol. Genet. 2009, 18, R169-R176. [CrossRef]

161. Laughlin, S.B.; de Ruyter van Steveninck, R.R.; Anderson, J.C. The metabolic cost of neural information. Nat. Neurosci. 1998, 1, 36-41. [CrossRef] 
162. Yoon, W.H.; Sandoval, H.; Nagarkar-Jaiswal, S.; Jaiswal, M.; Yamamoto, S.; Haelterman, N.A.; Putluri, N.; Putluri, V.; Sreekumar, A.; Tos, T.; et al. Loss of Nardilysin, a Mitochondrial Co-chaperone for alpha-Ketoglutarate Dehydrogenase, Promotes mTORC1 Activation and Neurodegeneration. Neuron 2017, 93, 115-131. [CrossRef] [PubMed]

163. Yamamoto, S.; Jaiswal, M.; Charng, W.L.; Gambin, T.; Karaca, E.; Mirzaa, G.; Wiszniewski, W.; Sandoval, H.; Haelterman, N.A.; Xiong, B.; et al. A drosophila genetic resource of mutants to study mechanisms underlying human genetic diseases. Cell 2014, 159, 200-214. [CrossRef] [PubMed]

164. Lake, N.J.; Compton, A.G.; Rahman, S.; Thorburn, D.R. Leigh syndrome: One disorder, more than 75 monogenic causes. Ann. Neurol 2016, 79, 190-203. [CrossRef] [PubMed]

165. Hegde, V.R.; Vogel, R.; Feany, M.B. Glia are critical for the neuropathology of complex I deficiency in Drosophila. Hum. Mol. Genet. 2014, 23, 4686-4692. [CrossRef] [PubMed]

166. Loewen, C.; Boekhoff-Falk, G.; Ganetzky, B.; Chtarbanova, S. A Novel Mutation in Brain Tumor Causes Both Neural Over-Proliferation and Neurodegeneration in Adult Drosophila. G3 (Bethesda) 2018, 8, 3331-3346. [CrossRef] [PubMed]

167. Schonrock, N.; Humphreys, D.T.; Preiss, T.; Gotz, J. Target gene repression mediated by miRNAs miR-181c and miR-9 both of which are down-regulated by amyloid-beta. J. Mol. Neurosci. 2012, 46, 324-335. [CrossRef]

168. Ylikallio, E.; Poyhonen, R.; Zimon, M.; De Vriendt, E.; Hilander, T.; Paetau, A.; Jordanova, A.; Lonnqvist, T.; Tyynismaa, H. Deficiency of the E3 ubiquitin ligase TRIM2 in early-onset axonal neuropathy. Hum. Mol. Genet. 2013, 22, 2975-2983. [CrossRef]

169. Boulay, J.L.; Stiefel, U.; Taylor, E.; Dolder, B.; Merlo, A.; Hirth, F. Loss of heterozygosity of TRIM3 in malignant gliomas. BMC Cancer 2009, 9, 71. [CrossRef]

170. Lin, P.Y.; Chang, S.N.; Hsiao, T.H.; Huang, B.T.; Lin, C.H.; Yang, P.C. Association Between Parkinson Disease and Risk of Cancer in Taiwan. JAMA Oncol. 2015, 1, 633-640. [CrossRef]

171. Ye, R.; Shen, T.; Jiang, Y.; Xu, L.J.; Si, X.L.; Zhang, B.R. The Relationship between Parkinson Disease and Brain Tumor: A Meta-Analysis. PLoS ONE 2016, 11. [CrossRef]

172. Morris, L.G.T.; Veeriah, S.; Chan, T.A. Genetic determinants at the interface of cancer and neurodegenerative disease. Oncogene 2010, 29, 3453-3464. [CrossRef] [PubMed]

173. Katzenberger, R.J.; Loewen, C.A.; Wassarman, D.R.; Petersen, A.J.; Ganetzky, B.; Wassarman, D.A. A Drosophila model of closed head traumatic brain injury. Proc. Natl. Acad. Sci. USA 2013, 110, E4152-E4159. [CrossRef] [PubMed]

174. Katzenberger, R.J.; Ganetzky, B.; Wassarman, D.A. Age and Diet Affect Genetically Separable Secondary Injuries that Cause Acute Mortality Following Traumatic Brain Injury in Drosophila. G3 (Bethesda) 2016, 6, 4151-4166. [CrossRef] [PubMed]

175. Katzenberger, R.J.; Chtarbanova, S.; Rimkus, S.A.; Fischer, J.A.; Kaur, G.; Seppala, J.M.; Swanson, L.C.; Zajac, J.E.; Ganetzky, B.; Wassarman, D.A. Death following traumatic brain injury in Drosophila is associated with intestinal barrier dysfunction. eLife 2015, 4, e04790. [CrossRef]

176. Mackay, T.F.; Richards, S.; Stone, E.A.; Barbadilla, A.; Ayroles, J.F.; Zhu, D.; Casillas, S.; Han, Y.; Magwire, M.M.; Cridland, J.M.; et al. The Drosophila melanogaster Genetic Reference Panel. Nature 2012, 482, 173-178. [CrossRef]

177. Barekat, A.; Gonzalez, A.; Mauntz, R.E.; Kotzebue, R.W.; Molina, B.; El-Mecharrafie, N.; Conner, C.J.; Garza, S.; Melkani, G.C.; Joiner, W.J.; et al. Using Drosophila as an integrated model to study mild repetitive traumatic brain injury. Sci. Rep. 2016, 6, 25252. [CrossRef] [PubMed]

178. Sen, A.; Gurdziel, K.; Liu, J.; Qu, W.; Nuga, O.O.; Burl, R.B.; Huttemann, M.; Pique-Regi, R.; Ruden, D.M. Smooth, an hnRNP-L Homolog, Might Decrease Mitochondrial Metabolism by Post-Transcriptional Regulation of Isocitrate Dehydrogenase (Idh) and Other Metabolic Genes in the Sub-Acute Phase of Traumatic Brain Injury. Front. Genet. 2017, 8, 175. [CrossRef]

179. Anderson, E.N.; Gochenaur, L.; Singh, A.; Grant, R.; Patel, K.; Watkins, S.; Wu, J.Y.; Pandey, U.B. Traumatic injury induces stress granule formation and enhances motor dysfunctions in ALS/FTD models. Hum. Mol. Genet. 2018, 27, 1366-1381. [CrossRef]

180. Lateef, S.; Holman, A.; Carpenter, J.; James, J. Can Therapeutic Hypothermia Diminish the Impact of Traumatic Brain Injury in Drosophila melanogaster? J. Exp. Neurosci. 2019, 13, 1179069518824852. [CrossRef] 
181. Putnam, L.J.; Willes, A.M.; Kalata, B.E.; Disher, N.D.; Brusich, D.J. Expansion of a fly TBI model to four levels of injury severity reveals synergistic effects of repetitive injury for moderate injury conditions. Fly (Austin) 2019, 13, 1-11. [CrossRef]

182. Lee, D.C.; Vali, K.; Baldwin, S.R.; Divino, J.N.; Feliciano, J.L.; Fequiere, J.R.; Fernandez, M.A.; Frageau, J.C.; Longo, F.K.; Madhoun, S.S.; et al. Dietary Supplementation With the Ketogenic Diet Metabolite Beta-Hydroxybutyrate Ameliorates Post-TBI Aggression in Young-Adult Male Drosophila. Front. Neurosci. 2019, 13, 1140. [CrossRef] [PubMed]

183. Sanuki, R.; Tanaka, T.; Suzuki, F.; Ibaraki, K.; Takano, T. Normal aging hyperactivates innate immunity and reduces the medical efficacy of minocycline in brain injury. Brain Behav. Immun. 2019, 80, 427-438. [CrossRef] [PubMed]

184. Fischer, J.A.; Olufs, Z.P.G.; Katzenberger, R.J.; Wassarman, D.A.; Perouansky, M. Anesthetics Influence Mortality in a Drosophila Model of Blunt Trauma With Traumatic Brain Injury. Anesth. Analg. 2018, 126, 1979-1986. [CrossRef] [PubMed]

185. Ghannad-Rezaie, M.; Wang, X.; Mishra, B.; Collins, C.; Chronis, N. Microfluidic chips for in vivo imaging of cellular responses to neural injury in Drosophila larvae. PLoS ONE 2012, 7, e29869. [CrossRef]

186. Mishra, B.; Ghannad-Rezaie, M.; Li, J.X.; Wang, X.; Hao, Y.; Ye, B.; Chronis, N.; Collins, C.A. Using Microfluidics Chips for Live Imaging and Study of Injury Responses in Drosophila Larvae. JoVE J. Vis. Exp. 2014, 84, e50998. [CrossRef]

187. Xiong, X.; Wang, X.; Ewanek, R.; Bhat, P.; Diantonio, A.; Collins, C.A. Protein turnover of the Wallenda/DLK kinase regulates a retrograde response to axonal injury. J. Cell Biol. 2010, 191, 211-223. [CrossRef]

188. Stone, M.C.; Nguyen, M.M.; Tao, J.; Allender, D.L.; Rolls, M.M. Global Up-Regulation of Microtubule Dynamics and Polarity Reversal during Regeneration of an Axon from a Dendrite. Mol. Biol. Cell 2010, 21, 767-777. [CrossRef]

189. Song, Y.Q.; Ori-McKenney, K.M.; Zheng, Y.; Han, C.; Jan, L.Y.; Jan, Y.N. Regeneration of Drosophila sensory neuron axons and dendrites is regulated by the Akt pathway involving Pten and microRNA bantam. Gene Dev. 2012, 26, 1612-1625. [CrossRef]

190. Li, D.; Li, F.; Guttipatti, P.; Song, Y.Q. A Drosophila In Vivo Injury Model for Studying Neuroregeneration in the Peripheral and Central Nervous System. JoVE J. Vis. Exp. 2018, 135, e57557. [CrossRef]

191. Stone, M.C.; Albertson, R.M.; Chen, L.; Rolls, M.M. Dendrite Injury Triggers DLK-Independent Regeneration. Cell Rep. 2014, 6, 247-253. [CrossRef]

192. Lu, W.; Lakonishok, M.; Gelfand, V.I. Kinesin-1-powered microtubule sliding initiates axonal regeneration in Drosophila cultured neurons. Mol. Biol. Cell 2015, 26, 1296-1307. [CrossRef]

193. Lee, T.; Marticke, S.; Sung, C.; Robinow, S.; Luo, L. Cell-autonomous requirement of the USP/EcR-B ecdysone receptor for mushroom body neuronal remodeling in Drosophila. Neuron 2000, 28, 807-818. [CrossRef]

194. Watts, R.J.; Hoopfer, E.D.; Luo, L. Axon pruning during Drosophila metamorphosis: Evidence for local degeneration and requirement of the ubiquitin-proteasome system. Neuron 2003, 38, 871-885. [CrossRef]

195. Awasaki, T.; Ito, K. Engulfing action of glial cells is required for programmed axon pruning during Drosophila metamorphosis. Curr. Biol. 2004, 14, 668-677. [CrossRef] [PubMed]

196. Hoopfer, E.D.; McLaughlin, T.; Watts, R.J.; Schuldiner, O.; O'Leary, D.D.; Luo, L. Wlds protection distinguishes axon degeneration following injury from naturally occurring developmental pruning. Neuron 2006, 50, 883-895. [CrossRef]

197. Yaniv, S.P.; Issman-Zecharya, N.; Oren-Suissa, M.; Podbilewicz, B.; Schuldiner, O. Axon Regrowth during Development and Regeneration Following Injury Share Molecular Mechanisms. Curr. Biol. 2012, 22, 1774-1782. [CrossRef]

198. Prithviraj, R.; Trunova, S.; Giniger, E. Ex vivo culturing of whole, developing Drosophila brains. J. Vis. Exp. 2012, 65, e4270. [CrossRef]

199. Ayaz, D.; Leyssen, M.; Koch, M.; Yan, J.K.; Srahna, M.; Sheeba, V.; Fogle, K.J.; Holmes, T.C.; Hassan, B.A. Axonal injury and regeneration in the adult brain of Drosophila. J. Neurosci. 2008, 28, 6010-6021. [CrossRef] [PubMed]

200. MacDonald, J.M.; Beach, M.G.; Porpiglia, E.; Sheehan, A.E.; Watts, R.J.; Freeman, M.R. The Drosophila cell corpse engulfment receptor Draper mediates glial clearance of severed axons. Neuron 2006, 50, 869-881. [CrossRef] 
201. Lu, T.Y.; MacDonald, J.M.; Neukomm, L.J.; Sheehan, A.E.; Bradshaw, R.; Logan, M.A.; Freeman, M.R. Axon degeneration induces glial responses through Draper-TRAF4-JNK signalling. Nat. Commun. 2017, 8. [CrossRef]

202. Fang, Y.; Bonini, N.M. Axon degeneration and regeneration: Insights from Drosophila models of nerve injury. Annu. Rev. Cell Dev. Biol. 2012, 28, 575-597. [CrossRef] [PubMed]

203. Soares, L.; Parisi, M.; Bonini, N.M. Axon Injury and Regeneration in the Adult Drosophila. Sci. Rep.-Uk 2014, 4, 6199. [CrossRef] [PubMed]

204. Neukomm, L.J.; Burdett, T.C.; Gonzalez, M.A.; Zuchner, S.; Freeman, M.R. Rapid in vivo forward genetic approach for identifying axon death genes in Drosophila. Proc. Natl. Acad. Sci. USA 2014, 111, 9965-9970. [CrossRef] [PubMed]

205. Moreno, E.; Fernandez-Marrero, Y.; Meyer, P.; Rhiner, C. Brain regeneration in Drosophila involves comparison of neuronal fitness. Curr. Biol. 2015, 25, 955-963. [CrossRef]

206. Leyssen, M.; Ayaz, D.; Hebert, S.S.; Reeve, S.; De Strooper, B.; Hassan, B.A. Amyloid precursor protein promotes post-developmental neurite arborization in the Drosophila brain. EMBO J. 2005, 24, 2944-2955. [CrossRef]

207. Fernandez-Hernandez, I.; Rhiner, C.; Moreno, E. Adult neurogenesis in Drosophila. Cell Rep. 2013, 3, $1857-1865$. [CrossRef]

(C) 2020 by the authors. Licensee MDPI, Basel, Switzerland. This article is an open access article distributed under the terms and conditions of the Creative Commons Attribution (CC BY) license (http://creativecommons.org/licenses/by/4.0/). 